\title{
A crise e uma crise na vida de uma atriz, de Søren Kierkegaard
}

Lucas Piccinin Lazzaretti ${ }^{1}$

\section{Introdução}

O filósofo dinamarquês Søren Kierkegaard considerou que seu trabalho autoral havia se encerrado com as publicações realizadas em 1846, de modo que 1847 seria o ano de encerramento de uma fase e, como pensava o autor, deveria ser o momento para uma nova posição existencial. Entre 1838 e 1846, considerando a redação e a publicação, Kierkegaard havia trazido à luz cerca 20 livros - um movimento que começara com um pequeno livro que se valia do subterfúgio de apresentar-se como uma suposta resenha literária, Dospapéis de alguém que ainda vive, e terminara em março de 1846 com outro pequeno livro que se valia do mesmo subterfúgio e trazia no título precisamente a sua armadilha: Uma resenha literária. Em meio a isso, desde 1843, Kierkegaard havia iniciado com o livro Enten-Eller (Ou isso... ou aquilo...) a sua produção pseudonímica, produção essa que permitiria o aparecimento de textos tais como Temor e tremor, $A$ Repetição, $O$ conceito de angústia, Migalhas Filosóficas e, por fim, terminaria, em fevereiro de 1846, com o volumoso Pós-escrito conclusivo não-científico às Migalhas Filosóficas. Foi com este último livro, inicialmente assinado pelo pseudônimo Johannes Climacus, que Kierkegaard teria retirado a máscara de sua invenção, deixando ver, em um pequeno subcapítulo final intitulado Uma primeira e última explicação, que ele era o autor de todos aqueles

1 Lucas Piccinin Lazzaretti é doutor em filosofia pela Pontifícia Universidade Católica do Paraná (PUC-PR). Foi visiting scholar na Hong-Kierkegaard Library no St. Olaf College em 2014 e 2017, e recebeu, pela mesma instituição, a posição de Fellow para o período de 2018/2019. Publicou recentemente a tradução de Como se faz uma novela pela editora UFPR e o romance Sombreir pela editora 7letras. 
livros. Com isso, o ciclo deveria estar fechado. Não se tratava apenas de abandonar o uso de pseudônimos, mas de abandonar certos temas e certas perspectivas.

Ao mesmo tempo em que o filósofo dinamarquês publicava argutos e dialeticamente refinados trabalhos com seus pseudônimos, também vinha publicando e produzindo os Discursos Edificantes sob sua própria pena, de tal modo que parecia querer criar alguma agitação com os temas trazidos de um e de outro lado. É com os pseudônimos que se realiza uma emulação estética, é com os pseudônimos que se tecem considerações éticas que se confrontam com aquelas apresentadas pelos filósofos da tradição alemã (Kant, Fichte, Schelling, Hegel, etc.) e é também com os pseudônimos que Kierkegaard pode mobilizar seu ataque ao pensamento e à cultura - tanto acadêmica quanto artística - de sua época, chegando ao ponto culminante de indicar simultaneamente tanto os erros quanto a abertura de possíveis caminhos através do Pós-escrito. Após tantos movimentos, tudo indicava que não haveria outras mobilizações a fazer, ou pelo menos não da mesma forma teatral e de certo modo performática. Seus contemporâneos pareciam dar mais valor aos textos estéticos do que às contradições existenciais que o filósofo buscava apresentar e, feita essa passagem de um âmbito de emulação para um âmbito de maior assertividade autoral, Kierkegaard não sentia que ainda teria algo a contribuir nos mesmos termos.

O interesse pela literatura, pela ópera e pelo teatro esteve presente desde o começo da produção de Kierkegaard. Contudo, uma vez que esta havia sido a marca dos escritos estéticos, nos quais não apenas os temas mas também os tratamentos eram delineados pelo que Kierkegaard considerava como o ponto de vista estético, naquele momento parecia difícil escrever mais uma vez sobre estas questões. O tratamento dado ao Don Giovanni, às muitas personagens de Goethe, a Hamlet e à questão do drama soava aos ouvidos do público claramente como um tratamento estético, mas o filósofo queria então diferenciar-se, partindo do modo de existência estético e problematizando-o para então alcançar o que ele chamaria de "o mais elevado".

É nesse ponto que se encontrava o autor quando, em 1847, iniciou a redação do ensaio de admiração e reflexão sobre as atividades teatrais de Johanne Luise Heiberg. A atriz, que então contava com 31 anos, fora uma sensação dos palcos dinamarqueses desde sua juventude, e em 1847, embora continuasse atuando, já não contava com o mesmo encanto e beleza juvenis que antes a garantiam como uma atração constante. $\mathrm{O}$ ensaio fora planejado conjuntamente com outros três escritos, que seguiriam a intenção de novamente mergulhar no mesmo jogo pseudonímico que Kierkegaard supostamente abandonara. Em uma nota de seus Diários o filósofo escreve: 
Eu gostaria de criar uma pequena mistificação literária, como, por exemplo, publicando algo que eu chamaria de "Trabalhos de Juventude", e em cujo prefácio eu apareceria como um jovem autor que estaria publicando sua primeira obra.

Eu me chamaria Felix de St. Vicent, e o conteúdo seria:

1) A crise na vida de uma atriz.

2) Eulogia do outono.

3) Rosenkilde como Hummer.

4) Provas de Escrita. ${ }^{2}$

O plano jamais foi realizado e apenas o primeiro ensaio viria a ser realmente finalizado e publicado ${ }^{3}$, agora não mais com o mesmo título e nem tampouco com o pseudônimo inicialmente indicado, mas com um novo pseudônimo: Inter et Inter. A escolha desse pseudônimo merece alguma atenção, porque Kierkegaard sempre esteve muito atento para o uso conceitual e filosófico da noção de interesse, ou seja, de um ser-entre. Não é acaso que um pseudônimo que, em uma tradução literal, poderia ser chamado de Entre e Entre, isto é, como uma duplicação da condição de estar-entre, apareça precisamente no momento em que seu criador não se encontrava nem de um nem de outro lado.

Muito se tem debatido entre os comentadores sobre quais seriam esses dois lados - se Kierkegaard estaria entre o primeiro movimento de produção pseudonímica (Johannes Climacus, Vigilius Haufniensis, Johannes de Silentio, etc.) e um segundo movimento dessa produção (sobretudo com Anti-climacus), ou então se Kierkegaard teria feito o tão aguardado salto para dedicar-se exclusivamente aos escritos de cunho religioso, já que seria, na leitura de alguns, um autor quase que

2 A nota em questão pode ser encontrada nos Papirer conforme a organização já consolidada por meio da entrada [VIII.1 A 339] ou na nova organização do Soren Kierkegaards Skrifter, por meio da entrada [SKS 20:225].

3 O planejado ensaio "Eulogia do outono", que já havia aparecido em 1845 em anotações, nunca foi finalizado, embora Kierkegaard tenha deixado esboços em seus Diários [VI A 89; SKS 18:261]; o ensaio "Rosenkilde como Hummer", que visava tratar da performance do ator Christian Niemann Rosenkilde quando este representou o papel de Hummer na peça de Johan Ludvig Heiberg, De Uadskillelige, não passou de uma página de esboço, a qual pode ser encontrada nos Diários [VIII.2 B 172-174; SKS 27:438], mas há que se considerar que Kierkegaard não abandonou a ideia de analisar o esforço dos atores, tendo terminado sua análise sobre Johanne Heiberg e, ao mesmo tempo, tendo esboçado, agora de forma mais completa, um ensaio sobre o ator Joachim Ludvig Phister, o qual recebeu o título "Sr. Phister como Capitão Scipio" e que se encontra também nos Diários [IX B 67-68; SKS 16:125]; finalmente, o ensaio denominado "Provas de Escrita" recebeu certo tratamento e cuidado, mas não foi plenamente concluído, constando igualmente nos Diários [VII.2 B 274 ss.] 
exclusivamente religioso. Poderia considerar-se ainda que Kierkegaard, partindo de um projeto filosófico bem conhecido e próprio do idealismo alemão, teria considerado - como antes o fizera seu professor Schelling - que aquele seria o momento de mover-se do negativo para o positivo, estando os conceitos pensados não em termos puramente religiosos, mas sobretudo filosóficos. Em todo caso, estas seriam apenas especulações que aqui parecem não ter serventia.

O que se sabe de fato, porque foi o próprio filósofo quem evidenciou, é que se tratava de poder, a partir daquele momento, analisar temas de cunho "estético" de outra maneira, valendo-se de categorias, conceitos e de uma estrutura "mais elevada". Isto significa dizer que Kierkegaard tinha a intenção de voltar ao ponto de onde partira em Enten-Eller, do "ponto de vista estético", para agora tratar um problema estético por outro ponto de vista, fosse ele religioso ou simplesmente entendido como "mais elevado".

Após ter finalizado a escrita do ensaio em 1847, o filósofo ficou em dúvida se seria o caso de publicá-lo e, depois de algum tempo de reflexão, decidiu por levá-lo ao público por meio de 4 participações no jornal Fadrelandet [A Pátria] entre 24 e 27 de julho de 1848. Suas dúvidas haviam esmorecido após a publicação, e Kierkegaard assim aponta em seus Diários:

Sim, foi bom ter feito a publicação daquele pequeno artigo. Comecei com Enten-Eller e com os Dois Discursos Edificantes; agora termino, após todo o desenvolvimento dos Discursos Edificantes - com um pequeno ensaio estético. Ele expressa: que é o edificante, o religioso que deveria ser transmitido, e que, agora que o estético foi transposto, eles estão opostos em uma relação inversa de confrontação para mostrar que o autor não era um autor estético que, com o passar dos anos, envelhecera e por essa razão se tornou religioso. (...) Haveria algo faltando se o pequeno artigo não tivesse vindo, a ilusão seria definida como se fosse eu que tivesse mudado significativamente ao longo dos anos, e então um ponto muito importante em toda a produção teria se perdido. ${ }^{4}$

4 Esse trecho, que pode ser encontrado nos Diários [IX A 227; SKS 21,56], avança para uma consideração reflexiva sobre o que Kierkegaard considerava ser sua função enquanto pensador e escritor. Algumas dessas reflexões depois foram retrabalhadas e desenvolvidas no escrito O ponto de vista de minha obra enquanto escritor, publicado postumamente. É com base nessas reflexões, e sobretudo porque Kierkegaard afirmaria, tanto nestas notas dos Diários quanto no referido texto, que ele considerava a si mesmo como um autor religioso, que muitos comentadores aceitaram esse como uma chave hermenêutica fundamental. Essa posição, contudo, deve ser tratada com cautela, pois muito facilmente esse caminho pode levar à 
Após essa reflexão do próprio autor, podemos então nos perguntar: do que trata, enfim, este ensaio? Aparentemente, trata de um caso particular da época de Kierkegaard: uma jovem atriz afamada que, após o transcurso dos anos, é adorada por conveniência e deixou de ser amada pelos dotes naturais que guardava em sua juventude - e agora, quando elogiada, o é apenas por gentileza e por aquilo que Kierkegaard chamará de galanteria. A Sra. Heiberg, esposa do poeta, dramaturgo e filósofo Johan Ludvig Heiberg, fazia parte do movimento de renovação da estética e dos costumes dinamarqueses. Muito embora o nome de Johanne Heiberg não tenha realmente figurado ao longo de todo ensaio, tanto o público quanto a própria atriz puderam compreender quem era o objeto de análise $\mathrm{s}^{5}$. Tudo indica, então, que se trata de uma análise sobre essa dificuldade enfrentada pela atriz: a crise de sua profissão e uma crise específica referente a ela, ou seja, o fato de que, ao ter envelhecido, algo de mais substancial e "mais elevado" tem de aparecer para que o encanto não apenas se mantenha, mas para que este se transforme e, ao fim, se revele no que seria o encanto autêntico e verdadeiro. Tudo isto está no ensaio e não é estranho que este pequeno escrito tenha suscitado o interesse de atrizes, atores e demais pessoas envolvidas com as artes cênicas.

No entanto, é sempre preciso desconfiar de Kierkegaard, e a anotação em seus Diários referenciada acima indica que há no ensaio, também, uma reflexão que vai além do âmbito do teatro e da função cênica de uma atriz específica. Se o objeto de análise inicialmente parece ser uma atriz, com um pouco de atenção percebe-se que esta atriz, como diria Kierkegaard, é a ocasião para se analisar algo mais profundo, isto é, para se analisar a metamorfose. O que o filósofo parece ter em vista aqui é a tentativa de dar conta de uma manifestação puramente estética em termos conceituais que levam em conta a profundidade dos elementos existenciais que ele já apresentara, por exemplo, em $A$ Repetição ou nos Estádios no caminho da vida. Ao mesmo tempo, como a anotação dos Diários indica, essa também é uma forma de esclarecer ao público - ainda que de um modo pouquíssimo esclarecedor - um pouco sobre a própria condição em que Kierkegaard encontrava-se. A atriz é uma ocasião que faz lado aos muitos exemplos trazidos pelo filósofo ao longo do

formulação de argumentos ad hoc. Para considerações críticas sobre esse debate, cf. JUSTO, José Miranda. Singularidade e Universalidade nos processos de leitura de Kierkegaard. In.: Revista de Filosofia Moderna e Contemporânea. Brasília, vol. 2, nº 1, 2014.

5 Em sua autobiografia, Et Liv gjenoplevet $i$ Erindringen [Uma vida revivida na memória], a atriz relembra do ensaio elogioso e diz-se muito feliz pelo que Kierkegaard escrevera sobre seu esforço e sua profissão. O próprio filósofo enviou o ensaio para a atriz três anos após sua publicação, o que também é recobrado na autobiografia. 
ensaio, seja no caso do poeta, no caso do escritor prolífico ou no caso do pregador afamado. A densidade do ensaio, com uma retórica muito bem controlada e com um contínuo avançar na apresentação e no uso de conceitos filosófico-dialéticos, se deve ao fato de que este "pequeno ensaio", como Kierkegaard o chamou, é talvez um dos mais fascinantes e mais bem arranjados exemplos da reflexão existencial desenvolvida por esse autor que nunca se contentou em ser um só. 


\title{
Krisen og en Krise i en Skuespillerindes Liv
}

\author{
Soren Kierkegaard
}

\section{I}

Tanken om det at være Skuespillerinde, det vil da sige af Rang, vækker vistnok hos de Fleste strax Forestillingen om et saa fortryllende og glimrende Vilkaar i Livet, at derover som oftest ganske glemmes Tornene: de utrolig mange Trivialiteter, al den Ubillighed eller dog den Misforstand just i de afgjørende Øieblik, mod hvilke en Skuespillerinde kan have at kæmpe.

Lad os tænke os Forholdet saa gunstigt som muligt; lad os tænke en Skuespillerinde, der er i Besiddelse af Alt hvad der fordres, for ubetinget at være rangerende; lad os tænke, at hun vinder Beundringens Anerkjendelse, og at hun (hvad upaatvivleligt er et stort Held) er heldig nok til ikke at blive Maalet for et eller andet hadefuldt Menneskes Forfølgelse: saalever hun da hen Aar efter Aar den misundte, den lykkelige Gjenstand for en stadigt vedvarende, anerkjendende Beundring. Det synes saa herligt, det seer ud som var det Noget; men naar man seer nøiere til og seer i hvilken Møntsort denne anerkjendende Beundring udredes, seer hvilket fattigt Indbegreb af lurvede Trivialiteter, der i Theaterkritikens Verden constituerer Fondet ad usus publicos (og det er jo af dette Fond at hin stadig anerkjendende Beundring ordenligvis udredes), saa turde det vel være muligt, at selv dette det heldigste Vilkaar for en Skuespillerinde er tarveligt og fattigt nok. - Er det saa som man siger, at det kongelige Theaters Garderobe skal være meget kostbar og værdifuld, saa er det vist: Bladkritikens Garderobe er rædsom lurvet.

Videre. Den beundrede Konstnerinde lever da hen Aar efter Aar. Som man i borgerlige Husholdninger nøiagtigt veed forud, hvad man hver Dag skal have til Middag, saaledes veed hun nøiagtigt forud Saisonens Accidenser. 2 à 3 Gange om Ugen bliver hun rost og beundret, indkaldt med Udmærkelse; allerede i Løbet af det første Fjerdingaar vil hun mere end een Gang have gjennemgaaet Bladkritikens Indbegreb af Talemaader ogVendinger, somde med særligt Eftertryk kunne kaldes, thi de vende i etvæk tilbage. 1 à 2 Gange, i gode Aaringer 3 Gange, vil hun blive besunget af et eller andet forulykket Subject eller en vordende Digter; hendes Portrait bliver malet til hver Konstudstilling; hun bliver lithographeret, og er Lykken hende meget gunstig anbringes hendes Portrait endog paa Lommetørklæder og Hattepulle. Og hun, der som Qvinde er øm over sit Navn - som en Qvinde, hun veed, at hendes Navn er paa Alles Læber, selv naar de tørre sig om Munden med Lommetørklædet, hun veed, at hun er Gjenstand for Alles beundrende Omtale, ogsaa deres, som ere i yderste Vaande for at faae Noget at snakke om. Saaledes lever hun hen Aar efter Aar. Det synes saa herligt, det seer ud som det var Noget, men forsaavidt hun 
skulde i ædlere Forstand leve af denne Beundringens kostelige Næring, hente Opmuntring fra den, styrkes og opflammes ved den til ny og ny Anstrængelse, forsaavidt dog selv det mest udmærkede Talent, og især da en Qvinde, i en svagere Time kan see sig mismodigt om efter en Yttring af virkelig Paaskjønnelse; saa vil hun, hvad hun naturligvis selv ofte har sandet, i et saadant Øieblik ret føle, hvor tomt alt Dette er, og hvor uretfærdigt, at misunde hende denne byrdefulde Herlighed.

Imidlertid gaaer der da Aar hen, dog i disse Nysgjerrighedens og Utaalmodighedens Tider ikke mange, saa kommer allerede Snakken i Bevægelse om, at hun nu begynder at blive ældre, og saa - ja, vi leve jo rigtignok i christelige Stater, men som man ofte nok seer Exempler paa æsthetisk Bestialitet, saa er det ogsaa langtfra at den kanibalske Lyst med Menneske-Offringer er gaaet af Brug i Christenheden. Den samme inderlige Fadhed, der uafbrudt til hendes Pris slog paa Trivialitetens store Tromme og ærede hende yndeligen paa Bækkener, den samme Fadhed bliver nu kjed af den forgudede Konstnerinde, den vil have hende bort, vil ikke see hende mere, hun maa takke Gud til, om den ikke vil have hende slaaet ihjel; den samme Fadhed faaer sig en ny 16 Aars Afgud, og til Ære for hende skal den forhenværende Afgud føle Trivialitetens hele Unaade - thi det er den store Vanskelighed, som er forbunden med at være Afgud, at det næsten er utænkeligt at man fra denne Ansættelse kan faae Afsked i Naade. Eller indtræder dette Tilfælde ikke, og ikke saa grelt som her er fremsat, saa skeer der stundom noget Andet, som synes meget bedre, men i Grunden er lige saa slemt. Trivialiteten er da ved Tilløbet fra Fortiden i saa god Fart med Beundringen, at den Forgudede endnu en tidlang, efter at hun, som det hedder, er bleven ældre, faaer Lov at gaae for Slutnings-Hastigheden. Tilsyneladende er der ingen Forandring foregaaet i Trivialitetens Udtryk om den forgudede Konstnerinde; dog synes man at ane en vis Usikkerhed, som forraader, at den lovprisende Rosiflengius saa smaat indbilder sig, at have den Fortjeneste af Konstnerinden, at han galant vedbliver at sige det samme. Men det at være galant mod en Konstnerinde er netop den høieste Grad af Uforskammenhed, en klæbrig Næsvished og den modbydeligste Art Paatrængenhed. Enhver, der er Noget og væsenligen er Noget, har eo ipso en Fordring paa nøiagtigt at blive anerkjendt for dette Bestemte, for hverken mere eller mindre. - Er det saaledes, som der jo siges, at Theatret er en Helligdom: Profanationen er i det mindste ikke langt borte. Hvor byrdefuldt og pinligt, i det 16de Aar at maatte taale gamle skaldede eller halvfjantede Recensenters hykkelske Knæfald og Kjærlighedserklæringer i Skikkelse af Konstkritik, hvor bittert i en senere Tid at maatte døie Galanteriets Frækhed!

Men hvoraf nu dette Umenneskelige, som dog afstedkommer saa megen Ubillighed ja Grusomhed mod de til Konstens Tjeneste indviede Qvinder, hvoraf, uden deraf, at æsthetisk Dannelse er saa sjelden blandt Menneskene. De fleste Menneskers Konstkritik i Forhold til det Qvindelige har væsenligen Kategori og Tankegang tilfælles med enhver Slagtersvend, Garderofficier, Handels-Commis, der taler begeistret om en forbandet nydelig og satans rask Tøs paa 18 Aar. Disse 18 Aar, denne forbandede Nydelighed og denne Satans Raskhed, det er Konstkritiken - og tillige dens Bestialitet. Derimod, der hvor, æsthetisk seet, Interessen ret egenligen begynder, der hvor det Indre bliver lykkeligt 
og med intensiv Betydning aabenbar I Metamorphosen: der falde Menneskenes Mængde fra. Vedbliver man at beundre, saa mener man, at være galant, eller at være skaansom; thi naar hun blot er 30 Aar gammel, saa er hun i Grunden perdue!

Det var virkeligt at ønske, især for Menneskenes egen Skyld, for at de ikke skulle være udelukkede eller udelukke sig selv fra de betydningsfuldeste Nydelser, om man kunde faae denne Fordom tilgavns udryddet. Og en Fordom er det virkelig, ja en bestialsk Fordom; thi det er ikke saa, at en Qvinde bliver Skuespillerinde i sit 18de Aar, hun bliver det snarere i sit 30te, eller senere, hvis hun bliver det, thi denne Spillen Comedie i det 18de Aar er, æsthetisk seet, af tvivlsom Art. Det er saa langt fra at være Galanteri at begynde sin Beundring med Udviklingens anden Gang, at det Modsatte let er Lefleri: at beundre en lille Jomfru paa 16 Aar. Jeg troer ikke ret paa, at en væsenlig dannet Æsthetiker kunde overtale sig til at gjøre en Skuespillerinde paa 16 Aar til Gjenstand for en Kritik, især hvis hun var meget smuk osv.; han vilde upaatvivleligt perhorrescere denne Tvetydighed. Det er sandt, det vil ofte hænde, at den, der har gjort Furore som 18 Aars Pige, ikke trænger igjennem. Faaer saa at være; men saa har hun heller ikke væsenligen været Skuespillerinde, saa har hun gjort Furore paa Scenen aldeles i samme Forstand, som naar en ung Pige gjør Furore een Vinter eller to i det Venskabelige. Derimod er det ogsaa sandt, at naar det lykkes med Metamorphosen, da kan der ikke være Tale om Galanteri; thi da først og da just er Beundringen, æsthetisk forstaaet, for Alvor i sin Ret.

See, der gjøres jo naturligvis meget ved Theatret for at sikkre Skuespillerindernes Fremtid: jeg troer, at det ogsaa vilde være meget gavnligt, om man fik denne aldeles uæsthetiske Overtro paa de 18 Aar ret udryddet, og fik det gjort ret indlysende, at den betydningsfulde Afgjørelse indtræder langt senere - ogsaa dette vilde jo være til Betryggelse for Skuespillerindernes Fremtid. Og Sagen selv har ikke blot æsthetisk, men ogsaa i høi Grad psychologisk Interesse, saa det forundrer mig, den ikke oftere gjøres til Gjenstand for Overveielse. Det Interessante er, ved Hjælp af det Psychologiske rent æsthetisk at kunne beregne Metamorphosen, eller dog at kunne forklare den, naar den er indtraadt.

En lille Artikel i et Blad er imidlertid ikke det Sted, der egner sig for en udførligere Undersøgelse, som gjennemgaaer flere Tilfælde. Her vil jeg derfor blot forsøge rent psychologisk og æsthetisk at skildre een Metamorphose, vistnok en vanskelig, men just derfor ogsaa en skjøn og betydningsfuld. Jo mere der nemlig har været givet og jo mere der altsaa har været indsat paa første Udtræk, desto vanskeligere er det at faae et nyt Udtræk, og jo mere et dog i Grunden uæsthetisk Publicum forgudende og støiende har været opmærksomt paa det Første, desto lettere forvandles dette samme Publicum til en ængstelig, mistænksom eller endog tvær Modstand mod Metamorphosen. En Skuespillerinde, der aldrig har havt det Held at være i afgjort Besiddelse af det, der i saa høi Grad fængsler og fortryller de uæsthetiske Tilskuere, kan maaskee, som Vederlag derfor, have Held til i al Stilhed at gjøre sin Metamorphose. Ogsaa dette er skjønt, og netop at det gaaer saa stille af, men det er ogsaa lettere, just fordi den Metamorphosen forberedende stille Forvandling ikke efterstræbes af Nysgjerrighed og ikke forstyrres af Misforstand, men er unddraget Publicums Indfald og Nykker. Thi Publicum er underligt; naar Tiden i Løbet 
af 10 Aar f. Ex.har taget sig den Frihed at gjøre dets erklærede Yndling - 10 Aar ældre: saa bliver Publicum vred - paa Yndlingen.

\section{II}

Ieg tænker mig altsaa en Skuespillerinde i hendes første Begynden, i hendes tidlige Ungdoms første Lykke, i det Øieblik, da hun første Gang viste sig og første Gang gjorde glimrende Lykke. Dette kan jeg æsthetisk rigtigt her tale om og have Glæde af at tale om, thi denne Undersøgelse er ideel, beskæftiger sig ikke med en virkelig Skuespillerinde paa 16 Aar, der lever samtidigt. Ogsaa af en anden Grund er det her æsthetisk i sin Orden at skildre en saadan første Ungdom; thi da Undersøgelsens egenlige Gjenstand er Metamorphosen, saa er jeg end ikke i Afhandlingens Tanke samtidig med hin Ungdommelighed. Skildringen af det Første er for at lægge til Rette, er poetisk og philosophisk en Erindring, aldeles uden Veemod; der dvæles ikke ved det Første, tvertimod, der hastes snarere bort derfra, som man altid haster til det Høiere, og Forfatteren er jo æsthetisk overbevist om, at Metamorphosen er det Høieste.

Hun debuterer da i hendes 17de Aar. Hun er i Besiddelse af - ja, hvad det er hun er i Besiddelse af er meget vanskeligt at bestemme, just fordi det er et ubestemmeligt Noget, som dog almægtigt gjør sig gjældende, ubetinget lystres. Det vrantneste, det kedsommeligste Menneske, det hjælper ham ikke at han forhærder sig, han maa lystre; en Mathematiker, det hjælper ham ikke, at han sætter sig paa Bagbenene og siger, hvad beviser saa det, han maa lystre, han er i Grunden overbevist: ergo er hun i Besiddelse af - ja, hvad det er hun er i Besiddelse af er meget vanskeligt at bestemme, just fordi det er et ubestemmeligt Noget. Forunderligt. Ellers pleier man dog at kunne nøiagtigt angive hvad et Menneske er i Besiddelse af, og naar man saa kan det, saa kan man igjen nøiagtigt see, hvor langt han kommer med det - han er i Besiddelse af. Og derimod, en ung Skuespillerinde, der er i Besiddelse af denne ubestemmelige Besiddelse, hun forarmer ligesom i et $\mathrm{Nu}$ alle Eiendomsbesiddere!

Denne ubestemmelige Besiddelse er, for dog lidt nærmere at bestemme den: Lykke; hun er i Besiddelse af Lykke. Lykke betyder ikke her, at hun er saa heldig at have gode Venner og anselige Connexioner, eller saa heldig at være bleven antagen ved Theatret paa fordelagtigt Vilkaar, eller saa heldig, at Directeuren og Recensenterne interessere sig for hende; nei Lykke betyder her, hvad Cæsar talte med Skipperen om, da han sagde til ham: Du fører Cæsar - og hans Lykke. Ja, dersom det ikke var at udfordre Lykken, da kunde hun dumdristigt vove hver Aften, hun spiller, at lade sætte paa Placaten: Jfr. N. N. og hendes Lykke - i den Grad er hun i Besiddelse af Lykken. Hun har ikke Lykken med sig, og allerede dette er da saare meget, at denne almægtige Magt behager at give en ung Pige Geleide; nei Lykken selv staaer paa Pinde for hende. Og forsaavidt hun ikke skal siges at være i Besiddelse af Lykken, maatte det da være fordi hun er som besat af Lykken - i 
den Grad følger den hende, hvor hun gaaer og staaer, i Alt hvad hun foretager sig, i den mindste Bevægelse med Haanden, i ethvert Vink af Øiet, i ethvert Kast med Hovedet, i ethvert Sving af Skikkelsen, i Gangen, i Stemmen, i Mimiken, kort Lykken følger hende saaledes, at den ikke $\mathrm{i}$ et Secund tillader den konstforstandige Kritiker at see, hvad hun vilde formaae uden Lykken, om han end allerede er æsthetisk opmærksom paa, hvorvidt det Bedste af alt Dette dog ikke i en ganske anden Forstand tilhører hende.

Hendes ubestemmelige Besiddelse betyder videre, for dog at bestemme den lidt nærmere:Ungdommelighed. Dette betyder ikke det Statistiske, at hun accurat i Mandags otte Dage fyldte det 16de Aar, ei heller, at hun er en ung Pige, der paa Grund af Skjønhed og andet Saadant passende præsenteres til Skue og forsaavidt upassende kaldes en Skuespillerinde; nei, hendes Ungdommelighed er igjen en ubestemmelig Rigdom. Først og fremmest er den Livlighedens Spil af Kræfter, hvad man ogsaa kunde kalde Ungdommelighedens livsfriske, righoldige Uro, hvad man altid og uvilkaarligt taler med Forkjærlighed om, som naar det siges, at det lykkeligt begavede Barn er Uroen i Familien. Uro, naar derved forstaaes Endelighedens Spektakel, kan man snart faae nok af, men Uro i prægnant Forstand, Uendelighedens Uro, den glade, livsfriske Oprindelighed, derforyngende, forfriskende, helbredende rører Vandet, er en stor Sjeldenhed, og i denne Forstand er hun Uroen. Dog denne Uro betyder igjen Noget, og noget meget Stort, den betyder en væsenlig Genialitets første Vælighed. Og denne Uro betyder intet Tilfældigt, den betyder ikke, at hun ikke kan staae stille, tvertimod, den betyder, at selv naar hun staaer stille aner man denne Uro derinde vel at mærke i Ro. Den betyder ikke, at hun kommer løbende ind paa Scenen, tvertimod den betyder, at blot hun bevæger sig, aner man Uendelighedens Fart. Den betyder ikke, at hun taler saa hurtigt, at man ikke kan følge hende, den betyder tvertimod, at, naar hun taler ganske langsomt, fornemmer man Pustet og Beaandelsen. Denne Uro betyder En ikke, at hun snart maa blive træt, lige det Modsatte, den aabenbarer enelementarisk Utrættelighed, som Vindens, som Naturlydens; den aabenbarer, at Skjælmeriet er uudtømmelig rigt, at det bestandig kunforraader, at hun eier meget mere; den aabenbarer, at hendes Coquetteri (og aldeles uden Coquetteri er en saadan Skikkelse utænkelig) ikke er Andet end et lykkeligt, uskyldigt Sinds glade, seierrige Bevidsthed om sin ubeskrivelige Lykke. Dette er derfor egenligen ikke Coquetteri, men er dog et Incitament mere for Tilskueren; det betrygger nemlig Tilforladeligheden af det Hele, og betrygger Overgivenheden med absolut Sikkerhed.

Man skulde troe, at Tilforladelighed paa den ene Side, og paa den anden Side Skjælmeri, Livlighed, Lykke, Ungdommelighed vare aldeles uensartede Bestemmelser, som slet ikke hørte sammen. Dog er dette langtfra saa, de høre just absolut sammen. Dersom Skjælmeri og Livlighed ikke ubetinget er betrygget ved en absolut Tilforladelighed, at her er nok, nok for hende, nok for en halv Snes Andre: saa er det eo ipso uheldigt og Nydelsen væsenligen borte. Uadskilleligheden kan man ogsaa kjende derpaa, at der ganske conseqvent ligger et til Skjælmeri Svarende i at sætte Skjælmeri og Tilforladelighed sammen, som naar en ældre, men dog endnu livlig Mand med hele Forkjærligheden for en skjælmsk ung Pige siger: det er min Sandten en tilforladelig lille 
Jomfru; han siger ikke, at hun er skjælmsk, men at hun er tilforladelig, og dog siger han just derved at hun er skjælmsk, og dette er ikke hans Opfindelse, men hun ligesom afnøder ham dette Udsagn ved Skjælmeriet.

Man skulde troe, at Overgivenhed paa den ene Side, og absolut sikker Betryggelse paa den anden Side vare uensartede Bestemmelser, som slet ikke høre sammen, eller som kun Klodderagtighed kunde falde paa at sætte sammen; og dog ere de just uadskillelige, og det Dialektiske Opfinder af denne Sammensætning. Det gjælder om Alt, hvad der er Naturbestemmelse og som saadant et Enkelt, et Usammensat, at det maa være absolut sikkret. I hvad der er sammensat kan der bedre savnes Noget, men hvad der er Enkelt, er Umiddelbarhed, maa være absolut, eller, hvilket er det Samme, naar det er, er det absolut. Lidt Overgivenhed er eo ipso at forkaste som noget Uskjønt. Den rette Overgivenhed virker derfor, netop ved den absolute sikkre Betryggelse, først og fremmest beroligende paa Tilskueren, hvad dog maaskee undgaaer de Flestes Opmærksomhed, der mene, at Overgivenhed virker pirrende, hvilket kun gjælder om den uægte Overgivenhed eller om lidt Overgivenhed. Lad os tage et Exempel af den umiddelbare Comik, af Lune. Naar man en Aften seer Rosenkilde komme ind paa Scenen, ligesom directe fra Uendeligheden og med dennes Fart, besat af alle Lunets Aander, naar man strax ved dette første Syn uvilkaarligt siger til sig selv »naa, iaften har han en ordenlig Storm«: saa føler man sig eo ipso ubeskrivelig beroliget. Man aander ud netop for ret at slaae sig til Ro; man sætter sig tilrette, som den der agter længe at blive siddende i samme Stilling; man næsten beklager, at man ikke har taget Mad med, thi Vederhæftigheden og Betryggelsen, der overtaler til Beroligelse, er saa stor, at man glemmer, at der kun er Tale om en Time i Theatret. Medens man leer og leer, og i al Stilhed jubler med i Lunets Overgivenhed, føler man sig bestandig beroliget, ubeskrivelig overtalt og ligesom dysset ved den absolute Betryggelse, fordi hans Lune gjør det Indtryk paa En: dette kan blive ved saa længe det skal være. Og derimod, dersom en umiddelbar Comiker ikke først og fremmest absolut beroliger, dersom der blot bliver en lille Smule Angst i Tilskueren, om hvorvidt hans Lune vil strække til: saa er Nydelsen væsenligen tabt. Man taler ellers om, at en Comiker maa kunne faae Tilskuerne til at lee, rigtigere siger man maaskee: han maa først og fremmest kunne absolut berolige, saa kommer det af sig selv med Latteren; thi den rette Latter, denne Latter ret af Hjertens Grund, den bryder ikke frem ved en Pirring, men netop af en Beroligelse. Saaledes ogsaa med Overgivenhed: den maa først og fremmest berolige ved absolut Betryggelse, det vil sige, er den i Sandhed tilstede i en Skuespillerinde, saa virker den først absolut beroligende. Det er i denne Beroligelse, overtalt ved den absolute Betryggelse og Vederhæftighed, at Tilskueren igjen overgiver sig - i Overgivenheden. See, her er det atter: Overgivenhed og Vederhæftighed synes en underlig Sammensætning, at sige om Overgivenhed at den er vederhæftig en underlig Tale; og dog er det correct, og kun et nyt Udtryk for Skjælmeri, thi den vederhæftige Overgivenhed er just Skjælmeri.

Hendes ubestemmelige Besiddelse betyder videre, for dog lidt nærmere at bestemme den:Sjalfuldhed, at hun i umiddelbar Lidenskabs Stemning er samstemmende med Idee og Tanke; at hendes endnu ureflecterede Inderlighed er væsenligen i Pagt med Idealiteten; 
at enhver en Tankes eller Idees Berøring slaaer an, og giver fuldtonig Gjenklang; at hun er en oprindelig, specifik Modtagelighed. Saaledes forholder hun sig i Sjælfuldhed til Forfatterens Ord; men til sig selv forholder hun sig i det Mere, der ret egenligen maa kaldes Klangen i Forhold til Replikken, og Samklangen i Forholdet til hele Skikkelsen. Hun tager ikke blot Forfatteren Ordet rigtigt af Munden, men hun giver ham det saaledes igjen, at det i Skjælmeriets Medlyden, i Snildets Medviden om sig selv er som sagde hun tillige: kan Du gjøre mig det efter.

Hendes ubestemmelige Besiddelse betyder endeligen: at hun er $i$ den rette Rapport til den sceniske Spanding. Enhver Spænding kan, dette er det Dialektiskes egen Dialektik, virke paa en dobbelt Maade; den kan gjøre Anstrængelsen aabenbar, men den kan ogsaa gjøre det Modsatte, den kan skjule Anstrængelsen, og ikke blot skjule den, men bestandigt omsætte den i, forvandle og forklare den til Lethed. Letheden grunder da usynligt i Spændingens Anstrængelse, men denne sees ikke, den anes end ikke, kun Letheden aabenbares. En Tyngde kan tynge Noget ned, men den kan ogsaa omvendt skjule, at den tynger og udtrykke Tyngden ved det Modsatte, ved at hæve Noget i Veiret. I daglig Tale taler man om at gjøre sig let ved at afkaste Byrder, og denne Betragtning ligger til Grund for alle trivielle Livsanskuelser. I høiere, i poetisk og philosophisk Forstand, gjælder det Modsatte: man bliver let ved Hjælp af - Tyngde, man svinger sig høit og frit ved Hjælp af - et Tryk. Himmellegemerne svæve saaledes ved Hjælp af en stor Tyngde; Fuglen flyver ved Hjælp af en stor Tyngde; Troens lette Svæven er ved Hjælp af en uhyre Tyngde; Haabets høieste Sving er just ved Hjælp af Trængsel og Gjenvordigheders Tryk. Men den sceniske Illusion og Vægten af Alles Øine er en uhyre Tyngde, der lægges paa et Menneske; hvor derfor den lykkelige Rapport mangler, der vil end ikke Routine i nok saa høi Grad ganske kunne skjule Byrdens Tyngde, men hvor den lykkelige Rapport er, der forvandler Vægten af Byrden sig i eetvæk til Lethed. Saaledes med den unge Skuespillerinde; i Scenens Spænding er hun i sit Element, just der er hun let som Fuglen, netop Vægten giver hende Lethed, og Trykket giver det høie Sving. Der er ikke Spor af Angst; mellem Coulisserne er hun maaskee angest, men paa Scenen er hun lykkelig og let som Fuglen, der har faaet sin Frihed, thi nu først, i Trykket, er hun fri og har faaet Friheden. Hvad der hjemme paa Studereværelset, hvad der mellem Coulisserne viser sig som Angst, er ikke Afmagt, men lige det Modsatte, er Elasticitet, som ængster hende, just fordi hun ingen Tyngde har paa; i den theatralske Spænding forklarer denne Angst sig absolut lykkeligt som Potensation. Det er overhovedet en meget borneret Betragtning, at en Konstner eller Konstnerinde ikke maa være angest, og fremfor Alt et maadeligt Kjende paa den store Konstner, at han ikke er angest. Netop jo flere Kræfter han har, desto større er hans Angst, saa længe han er udenfor den Spænding, der nøiagtigt svarer til hans Kræfter. Dersom man tænkte sig den Naturkraft, der bærer Himmellegemerne, i en Personification udenfor sin Opgave, ventende paa at skulle overtage den: saa vilde den sidde i Dødsens Angst, og først i det Øieblik, den fik Byrden paa, vilde den være sorgløs og let. Derfor er det een af de største Qvaler for et Menneske, at have en for stor Elasticitet i Forhold til den lille Verdens Spænding, i hvilken han lever, en saadan Ulykkelig kommer aldrig til at føle sig ganske fri, 
netop fordi han ikke kan faae Tyngde nok paa sig. Sagen er kun, at Angsten slaaer absolut rigtig til, at den i Forhold til den sceniske Konstner bestandig er udenfor Scenen, aldrig paa Scenen, hvilket just pleier at hænde den, der ikke er angest udenfor.

Hendes bestemmelige Besiddelse er naturligvis let at angive. Hun har ikke blot naturlig Ynde, men hun har tillige Skole, hun har som tjenende Moment det Meste af hvad en Dandserinde sætter Alt ind paa. Hendes Diction er correct, nøiagtig, hendes Stemme ikke misbrugt, men dannet, uden Skrig, uden Hiatus slutter den sig helt og bestemt om Ordet, som hun ikke beholder hos sig eller for sig selv, men heller ikke ufrit giver fra sig; hun articulerer ypperligt, selv naar hun hvisker; hun veed at bruge Stemmen, og fremfor Alt, hvad der saa lykkeligt svarer til hendes Forudsætninger, at bruge den i den ubetydelige, den let henkastede, converserende Repliks Svinkeærinder.

Saa debuterer hun da i sit 17 de Aar. Hendes Optræden er naturligvis en Triumph; og i samme Øieblik forvandler hendes Tilværelse sig til et National-Anliggende. Som Regimentets Datter ansees af hele Regimentet for Datter, saaledes bliver hun Nationens Datter. Det blotte første Syn af hende er tilstrækkeligt til at forvisse Enhver om, at en saadan sjelden lykkelig qvindelig Begavethed vanskeligt findes i meer end eet Exemplar i hver Generation. Det bliver altsaa en National-Pligt at beundre, et fælles Anliggende at omfrede denne sjeldne Plante, ak, og om det just ikke kan kaldes en Pligt, saa bliver det dog en Selvfølge af den menneskelige Svaghed, at det bliver en Nysgjerrighedens Interesse at see, hvor længe hun nu kan holde sig. Ja, den menneskelige Glæde over det Sjeldne er besynderlig, næsten i Glædens første og høieste Øieblik begynder Nysgjerrighedens Snigmord. Dette er nemlig ikke Misundelse, langtfra, det er en Slags Forfippethed hos Beundringen, der saa at sige hverken veed ud eller ind for Jubel, indtil den ganske rigtigt hitter paa, strax i det første Aar at udvikle denne dræbende Spænding, der af pure Beundring næsten mistroisk beundrer.

For end engang at minde om, hvad der oftere er blevet fremsat: hvis der levede en væsenlig Æsthetiker samtidig og han opfordredes til at forsøge kritisk at vurdere denne Skuespillerinde eller en Præstation af hende, saa vilde han vistnok sige: nei, hendes Tid er endnu ikke egenligen kommen.

\section{III}

Der er gaaet 14 Aar, hun er i sit 31de. Igjennem disse ikke faa Aar har hun været en Gjenstand for hin stadigt beundrende Anerkjendelse. Lad mig antyde denne Tidens Forsvinden ved at benytte dette Mellemrum til nogle Betragtninger. Thi lad os ikke bedrageved Tilsyneladelsens løse Overslag over Accidensernes Totalsum og derved ledes tilubilligen at misunde hende Beundringen, lad os hellere betænke, hvor megen Klodderagtighed der blander sig i denne trivielle Anerkjendelses stadige Overhalinger; og fremfor Alt lad os ikke glemme, hvad det vil sige og betyde, at det dog egenligen i disse 14 Aar er blevet de Samtidige en Vane at beundre hende, lad os, hvis vi ville regne rigtigt, ikke, 
ubilligt mod hende, glemme at subtrahere dette fra Beundringens formentlige Herlighed. O, hvor sjeldent er der vel fundet et Menneske, end sige en Samtid, der ikke gav efter i Vanens Svig, saa selv om Udtrykket ikke forandredes, dette uforandrede Udtryk dog ved Vanen blev noget Andet, saa dette ordrette Samme dog nu lød saa svagt, saa mechanisk, saa ubetonet, skjønt der sagdes det samme. O, der tales i Verden meget om Forførere og Forførelser: men hvor Mange ere vel de, som ikke ved Vanen bedrages af dem selv, saa de synes uforandrede, men dog ere som udtærede i det indvortes Menneske; saa de vel elske de samme Mennesker, elske dem, men saa mat, saa fattigt; saa de vel bruge de samme ømme Udtryk, men saa svagt, saa kraftesløst, saa afsjælet. Dersom en Konge vilde besøge en ringe Familie - ja, den vilde føle sig udmærket, stolt, næsten overvældet af sin Lykke; men dersom Majestæten vilde vedblive hver Dag at besøge den samme Familie, hvor længe skulde det vel vare, inden Kongen næsten maatte gjøre Anstrængelser for dog at skaffe det lidt Betydning, at han besøgte Familien, der dog uforandret, af Vane vedblev at sige: vi takke for den store Ære. Af alle Sophister er Tiden den farligste, af alle farlige Sophister er Vanen den underfundigste. At man lidt efter lidt forandres i Aarene er allerede vanskeligt nok at blive opmærksom paa; men Vanens Svig er, at man er den uforandrede Samme, at man siger det uforandrede Samme, og dog er saa forandret, og dog siger det saa forandret.

Netop derfor have alle Sandhedens i Sandhed unyttige det er uegennyttige Tjenere, hvis Liv er idel Kamp med Tilværelsens Sophismer, hvis Bekymring ikke er, hvorledes man selv bedst kan komme derfra, men hvorledes man sandest kan tjene Sandheden og i Sandhed gavne Menneskene: de have vidst Besked om at benytte Sandsebedragene - for at prøve Menneskene. Naar saaledes en udmærket Mand lever meget skjult, naar han kun sjeldent viser sig, da forvænnes Menneskene ikke ved at see ham. Derimod udvikler der sig et ypperligt, et, si placet, hensigtsmæssigt Sandsebedrag: at denne Udmærkede maa være noget ganske Overordenligt, og hvorfor, er det fordi man veed at vurdere hans ypperlige Egenskaber; ak nei, - fordi man seer ham saa sjeldent, at dette sjeldne Syn frembringer en phantastisk Virkning. At dette lader sig gjøre, er en gammel Erfaring; Methoden, mesterlig udtrykt af Shakespeare i Henrik den 4des'Tiltale til Prinds Henrik, er med Held benyttet af en talrig Skare af Konger og Keisere og Geistlige og Jesuiter og Diplomater og kløgtige Hoveder o. s. v., iblandt hvilke der vistnok vare mange fortrinlige, adskillige som ogsaa vilde tjene Sandheden, men alle vare de dog enige i at ville virke ved Hjælp af et Sandsebedrag, hvad enten det nu var blot for selv at profitere deraf ved at sikkre sig Mængdens stupor, eller de fromt maaskee ogsaa kløgtigt mente, at skaffe Sandheden en almindeligere Udbredelse ved Hjælp af - et Sandsebedrag. De ubetinget uegennyttige Sandhedens Tjenere have derimod altid havt for Skik at færdes meget mellem Menneskene, de have aldrig leget Skjul med Mængden, for saa igjen at lege Forundringslegen, naar de den sjeldne Gang viste sig som Forundringens studsende Gjenstand, de have tvertimod altid vist sig ret egenligen i daglige Klæder, levet medden menige Mand, talt paa Gader og Stræder, givende Afkald paa al Anseelse - thi naar Mængden seer en Mand hver Dag, saa tænker Mængden som saa: ikke Andet. Ak ja, »mundus vult decipi«, men de uegennyttige Sandhedens Vidner have aldrig villet entrere paa dette Sandsebedrag, de have aldrig villet 
være halvt med Mængden om det Næste: »decipiatur ergo«, de have tvertimod bedraget ved det Modsatte, det er, de have dømt Verden ved at synes ubetydelige.

Dersom en Forfatter, som hverken har et betydeligt Fond af Ideer, ei heller er meget flittig, engang i Ny og Næ udgiver en pyntelig Examens-Skriverbog, der er særdeles nitid og med mange rene Blade elegant udstyret: saa seer Mængden med Forundring og Beundring dette pyntelige Phænomen; den tænker, har han været saa længe om at skrive den, og staaer der saa lidt paa Siden, saa maa det være noget Overordenligt. Dersom derimod en righoldig Forfatter, der har Andet at tænke paa end paa Pyntelighed, og paa at profitere af et Sandsebedrag, anstrængende sig med større og større Flid, seer sig istand til at kunne arbeide med en usædvanlig Hurtighed, saa bliver Mængden vant dertil, og tænker: det maa være Jadsk. Thi om Noget er udarbeidet eller ikke, kan Mængden naturligvis ikke bedømme, den holder sig til - Sandsebedraget. Dersom en Præst, som f. Ex. den forøvrigt saa høitbegavede afdøde Hofprædikant i Berlin, Theremim, kun prædiker hver ottende Søndag eller vel endog kun hver tolvte, men da ogsaa i Majestæternes og det hele kongelige Husesallerhøieste og høieste Nærværelse: saa udvikler der sig strax et Sandsebedrag i Forhold til en saadan Oberhofprædikant. Han bliver - ja, i Sandhed bliver han naturligvis hvad han i Sandhed er: den Høitbegavede, men i Mængdens Øine bliver han, foruden at være Oberhofprædikant, tillige Stadsprædikant, eller en stadselig Oberhofprædikant, noget Stadseligt, Noget lig Kongens Guld-Karreet, som man med Forbauselse seer et Par Gange om Aaret. Mængden vil studse: den vil i sin Visdom tænke saaledes: bruger en saadan Taler 3 Maaneder alene til at udarbeide en Prædiken og lære den udenad, saa maa den ogsaa være overordenlig. See, Trængselen paa den nysgjerrigt og længe forventede ottende eller tolvte Søndag var saa stor, at Oberhofprædikanten næsten ikke selv kunde slippe op paa Prædikestolen - havde han kun prædiket een Gang om Aaret, havde vel Trængselen været saa stor, at han ikke havde kunnet slippe ned igjen, eller at bevæbnede Gravere og Politibetjente vare blevne fornødne, for at skaffe den høiærværdige Oberhofprædikant Indgang og Udgang. Saa stor var Trængselen, og var det hændt, at En havde sat Livet til i Trængselen, saa var Trængselen næste Gang bleven endnu større, thi ikke blot i Forhold til Sandheden, men ogsaa i Forhold til Nysgjærrigheden, gjælder det: »sanguis martyrum est semen ecclesiæu.

Og nu en Skuespillerinde, der gjennem 14 Aar har været en stadig Gjenstand for Beundring. Man har jo nu saa ofte seet hende og sovet paa den Beundring; man veed jo, at hun bliver i Landet - thi er hun en af dem, der reise i Europa, saa kan hun dog have sit Haab til Sandsebedragets Assistance; man veed jo, hun maa blive her i Byen, thi i Danmark er der kun een By og eet Theater; man veed jo, hun maa spille, da hun er engageret; Mangen er, trods sin Beundring, dog maaskee uforskammet nok til at være vidende om, at hun maa spille, fordi det er hendes Næringsvei; man veed jo, at man kan faae hende at see, som oftest to Gange om Ugen. Det forstaaer sig, man vedbliver stadigt at beundre; men hvor Mange ere vel i en Samtid De, som vide at bevare den Inderlighedens og Skjønsomhedens Aarvaagenhed, at de i Beundringens 14de Aar kan see hende med samme Oprindelighed, med samme Oprindelighed, som hun bevarer! 
Nei, Menneskenes Slægt ligner ogsaa i denne Henseende Børnene paa Torvet, at naarde mærke, at de have Noget, kunne faae Lov at beholde det, saa blive de utaknemmelige, om ikke ligefrem utaknemmelige, saa dog dvaske i Beundringens Vane. Mod Ingen ere derfor Menneskene saa utaknemlige, som mod Gud, netop fordi de have en dvask Forestilling om, at ham kan man da altid have, - ak, han kan joikke engang ved at døe lade dem føle, hvad de tabte. O, menneskelige Beundring, hvor er duidel Forfængelighed, ikke mindst, naar du mener at være stadig!

Der er da ingen Forandring foregaaet i Beundringens og Anerkjendelsens Udtryk, kun i Betoningen; hin det første Indtryks spiritus asper er sagtnet i en forkrænkelig, tilvant Beundrings spagfærdigere Beaandelse. Skuespillerindens Actier staae uforandrede iden noterede Pris, dog ikke slet saa stive; en snigende, ængstelig, i Grunden velmenende, men dog ved sin Nysgjerrighed forræderisk Reflexion begynder at munkle om, at hun bliver ældre. Ingen vil vedgaae det, og dog siges det, og dog vil Ingen vedgaae at have sagt det. Netop fordi hendes Tilværelse har været et National-Anliggende er Forlegenhedens Spænding pinligere. Man mener hende det vel (thi hvad Del Enkeltes Misundelse kan have i en saadan Opinions Tilbliven, ville vi her ikke dvæle ved), man er egenlig vred paa Tiden, at den vil gjøre hende ældre, da man nu engang beqvemt har indrettet sig i den Beundringens Vane, at hun bestandig skulde blive 18 Aar; men dog, dog kan man ikke berolige sig i Forhold til denne Tanke om, at hun bliver ældre. Ingen tænker paa, hvorledes man utaknemmeligt gjør hende Metamorphosen vanskeligere og vanskeligere, hvorledes man utaknemmeligt lønner hende, ved at forvandle Erindringen til en Modstand i det afgjørende Øieblik; - og Ingen tænker paa, at dette Heleturde være Galimathias, som intetsteds har hjemme, mindst i Æsthetiken, da just med Metamorphosen hendes Tidsregning ret egenligen vil begynde.

\section{IV}

\section{(Sidste Artikel.)}

Altsaa nu til Metamorphosen. Det, der constituerede denne Skuespillerinde, var ikke, hvad man ellers kalder qvindelig Ungdommelighed. Saaledes forstaaet er denne Ungdommelighed Aarenes Bytte; om Tiden tager nok saa kjærligt, nok saa omhyggeligt, den tager alligevel dette Timelige. Men der var i denne Skuespillerinde en væsenlig Genialitet, som forholdt sig til den Idee: qvindelig Ungdommelighed. Dette er en Idee, og en Idee er noget ganske Andet end det Phænomenale selv at være 17 Aar gammel, hvilket jo ogsaa er den mest ideeløse Piges Tilfælde, der bliver 17 Aar gammel. Havde dette Genialitetens Forhold til Ideen ikke været, kunde der ikke være Tale om en Metamorphose; men netop fordi dette er Tilfældet, og Ideen er den, den er, kan Metamorphosen blive den sjeldne. Som Naturen ved sin Fremsynethed og ved sin erindrende Tilbageseen, hvad Naturforskerne skjønt have kaldt det Promethiske og det Epimethiske, bevarer Continuerligheden: saaledes 
maa ogsaa i Aandens Forhold Det, som egenligen skal constituere Metamorphosen, være tilstede fra Begyndelsen, medens det ikke afgjørende tages i Brug eller afgjørende viser sig som dette, førend der er gaaet nogen Tid - dette er just Metamorphosen.

Den, der kun har qvindelig Ungdommelighed ligefrem forstaaet, kan ingen Metamorphose faae, thi qvindelig Ungdommelighed saaledes forstaaet er ikke dialektisk i sig selv, er kun eet Liv, der ikke ved det Dialektiskes Tiltræden kan blive skilt og udsondret, men blot fortæret. Tiden er det Dialektiske, som kommer udenfra, og den fortærer derfor, hurtigt eller langsomt, den udialektiske Ungdommelighed. Men hvor der er eet Liv mere, der vil Tiden, idet den tager Noget af den ligefremme Ungdommelighed, netop gjøre Genialiteten mere aabenbar, og aabenbar i Idealitetens rent æsthetiske Forhold til Ideen. Hun vil naturligvis ikke blive ung igjen i den latterlige Forstand, hvori Slagtersvende og Publicum taler om en satans rask Tøs, men kun i Idealitetens Forstand vil hun blive ung og yngre. Hun er nu ret egenligen Gjenstand for en væsenlig Kritik, nu da hun anden Gang og $\mathrm{i}$ anden Potens kommer til at forholde sig til den samme Idee eller nøiagtigere udtrykt, netop fordi det er anden Gang, kommer hun til rent ideelt at forholde sig til Ideen. Sagen er ganske simpel; man kan spørge saaledes: hvilken Indfatning er den væsenligen tilsvarende til en Genialitet, hvis Idee er qvindelig Ungdommelighed. De fleste Mennesker ville desto værre formodenligen svare: det er qvindelig Ungdommelighed eller at være 17 Aar gammel. Men dette er vistnok en Misforstaaelse, som strider mod det Dialektiskes egen Tankegang. Rent ideelt og dialektisk er Fordringen: at Indfatningen, eller det hvori Ideen er, forholder sig til Ideen paa en Afstand fra Ideen. I Forhold til alle Naturbestemmelser gjælder det, at den første Gang er det Høieste, er Culminationen; i Idealitetens Forstand gjælder det, at den anden Gang er det Høieste, thi hvad er Idealitet Andet end just: den anden Gang. Ungdommelighedens Idee som Opgave og det selv at være aldeles ung svare i Idealitetens Forstand ingenlunde correct til hinanden. Forsaavidt uæs thetiske Tilskuere ere af den modsatte Mening, da er det fordi de bedrages af et Sandsebedrag, der forvexler Glæden over Jfr. N. N.'s phænomenale Ungdommelighed med Skuespillerindens væsenlige Idealitet. Lad os tage et andet Exempel. Der er en Lyrik, som man maatte kalde Ungdommelighedens Lyrik; ethvert ungt Menneske, der er erectioris ingenii, har lidt af den. Men saa er der et ungt Menneske, der qva Yngling har denne Ungdommelighedens Lyrik, og tillige har en Genialitet, hvis Idee er Ungdommelighedens Lyrik: nu spørges, naar vil han præstere sin bedste Lyrik, mon i det 20de Aar? Ingenlunde. Hans bedste Lyrik vil netop komme i en noget ældre Alder, naar Tiden har taget hans Ungdommeligheds lykkelige Tilfældigheder, saa han nu rent ideelt, og derved tillige i dybere Forstand tjenende forholder sig til sin Idee. De, der kun have Sands for hin første Ungdommeligheds lykkelige Tilfældigheder, de mangle æsthetisk Dannelse, og opdage derfor ikke, at dette Lykkelige er det Tilfældige, det Forgængelige, medens Genialiteten og Forholdet til Ideen er det Evige og Væsenlige.

Den betydeligste Opgave, der er sat en Skuespillerinde, som forholder sig til den Idee: qvindelig Ungdommelighed i dennes mest lyriske Potensation, er vistnok Julie i Romeo og Julie. Mon virkeligen nogen Æsthetiker vilde falde paa, at en Skuespillerinde paa 17 Aar kunde spille Julie? Man taler rigtignok trompetende om dette hele Spil af Kræfter, dette 
Fyr, denne Ild og dette meget andet Deslige; men man taler egenligen derom i Galleri-Kategorier, og Sligt strækker ikke til for at bedømme en Opfattelse af Julie. Det, Galleriet vil see, er naturligvis ikke en ideal Præstation, en Idealitetens Gjengivelse: Galleriet vil see Jfr. Julie, en satans nydelig og forbandet rask Tøs paa 18 Aar, der leger Julieeller udgiver sig for Julie, medens Galleriet forlystes ved den Tanke, at det er Jfr. N. N. Derfor kan Galleriet naturligvis aldrig faae det i sit Hoved, at en Skuespillerinde netop for at gjengive Julie maa væsenligen have en Afstand i Alder fra Julie. Og dog er det saaledes, og hint beundrede Overmaal af Kræfter i det 18de Aar egenligen, æsthetisk, en Misforstaaelse, thi i Idealiteten gjælder det: den bedste Kraft er Bevidstheden og Gjennemsigtigheden, der veed at disponere over de væsenlige Kræfter, vel at mærke i en Idees Tjeneste. Der gives vistnok Opgaver for en Skuespillerinde, i Forhold til hvilke de 18 Aar ere qvod desideratur: men disse Opgaver ere netop ikke de eminente Opgaver. Der er Opgaver, hvor dette Overmaal af den første Ungdommeligheds Kræfter, skal benyttes som en yndig Leg. Disse Opgaver kan da en saadan Skuespillerinde overtage, og det kan da betragtes som en skjøn, ogsaa betydningsfuld Tidsfordriv, indtil hun bliver saa meget ældre, at hun med de væsenlige Kræfter kan bære de eminente Opgaver. Atfremstille en lille Jomfru paa 16 Aar i et fransk Drama, det vil være den passende Opgave. Men denne flygtige, gækkende Skrøbelighed at løbe med er ogsaa som Intet at regne i Sammenligning med at skulle bære Vægten af Julies intensive Fylde. Det følger af sig selv, at det vilde være Misforstaaelse, at enhver, der engang kunde fremstille en saadan næsten kun skizzeret Figur, derfor ogsaa med Tiden skulde blive istand til at overtage de eminente Opgaver. Nei, langtfra. Men just derfor er det det Sjældne, naar Den, der absolut lykkeligt, bestandigt friskt og forynget dannede sig i de flygtige Bølgepigers lette Skikkelser, naar hun i Tidens Fylde forklarer sig i den eminente Hypostase.

Metamorphosen vil da blive: en, i eminent Forstand, Tilbagevenden til sit Første. Detteskal nu nærmere belyses ved at vise de dialektiske Bestemmelser i Metamorphosen. Tiden er, som sagt, det Dialektiske, der kommer udenfra, men hun var oprindelig dialektisk i sig selv, netop derfor kan hun gjøre Tiden Modstand, saa dens Dialektik kun gjør det Dialektiske i hende aabenbart - i Metamorphosen.

Tiden har gjort sin Ret gjældende; den har taget Noget af den umiddelbare, den første, den ligefremme, den tilfældige Ungdommelighed. Men derved vil Tiden igjen netop gjøre hendes Genialitet væsenligere aabenbar. Hun har tabt i Galleriets Øine, hun har vundet i Idealitetens Forstand. Galleri-Forvexlingernes Tid er forbi; skal hun spille Julie, kan der ikke mere være Tale om at gjøre furore som Jfr. Julie, skal hun spille den, maa det blive en eminent Præstation, eller endnu rigtigere en Præstation i eminent Forstand. Og dette er just Metamorphosen.Haardt mod Haardt hedder det, og saaledes ogsaa her: Dialektik mod Dialektik, saa har Tiden ingen Magt til egenligen at tage, den er kun en tjenende Magt, der tjener til at gjøre aabenbar.

Tiden har gjort sin Ret gjældende; den har taget Noget af hin første Ungdommeligheds lykkelige Tilfældigheder eller tilfældige Lykke, men den har tillige dannende og forædlende udviklet hende, saa hun nu i fuld og bevidst, i erhvervet og indviet Raadighed 
over sin væsenlige Kraft i Sandhed kan være sin Idees Tjenerinde, hvilket er det væsenlige æsthetiske Forhold og væsenligen forskjelligt fra det 17de Aars umiddelbare Forhold til den egne Ungdommelighed. Det er dette tjenende Forhold til Ideen, der egenligen er Culminationen, netop denne bevidste Sig-Ydmygen under Ideen er netop Udtrykket for Præstationens eminente Opløftelse. Det 17de Aars Ungdommelighed er meget for knibsk, meget for overmodig, meget for lykkelig til i dybeste, eller, hvilket er det Samme, i høieste Forstand at tjene. Men det, ganske at være tjenende, er Inderligheden; det 17de Aars Inderlighed er væsenlig en Higen ud efter, der i al sin Lykke dog aldrig kan være sikker for en eller anden Tilfældighed; eller hvis det undgaaes, at Tilfældigheden viser sig, maa man dog hver Gang sige: det var en Lykke, thi muligt er det bestandigt. Først i det absolut tjenende Forhold til Ideen er Tilfældigheden absolut gjort umulig.

Tiden har gjort sin Ret gjældende; der er et Noget, som er blevet forbigangent; men da vil igjen en Erindringens Idealitet kaste en høieste Belysning over hele Præstationen, et Incarnat, som end ikke var i hin den forste Ungdommeligheds Dage. Kun i Erindringen er der absolut Ro, og derfor just det Eviges stille Brand, dets uforkrænkelige Gløden. Og beroliget er hun i sin væsenlige Genialitets Evighed; hun vil ikke barnagtigt eller vemodigt længes efter det Svundnes Blussen, dertil er hun netop i Metamorphosen bleven baade for varm og for rig. Denne rene, beroligede og foryngende Erindren vil som et idealiserende Lys gjennemlyse hele Præstationen, der i dette Lys vil være ganske gjennemsigtig.

Disse ere Metamorphosens Momenter. Lad os nu blot til Slutning for endnu engang fra en anden Side at belyse dens Eiendommelighed, comparativt med den sammenstille en anden Metamorphose. Vi vælge en qvalitativ forskjellig; just dette vil give Sammenligningen væsenlig Interesse, medens det vil forhindre al nysgjerrig Qvantiteren betræffende hvilken der er den rareste osv. Denne anden Metamorphose er Continuerlighedens, hvilken igjen nærmere bestemmet er en Proces, en Succession, en stadig Forvandling i Aarene, saa Skuespillerinden, efterhaanden som hun bliver ældre, forandrer Fag, tager ældre Roller, igjen med samme Fuldendthed som hun i en yngre Alder udfyldte yngre. Denne Metamorphose kunde man kalde den ligefremme Perfectibilitet. Den har især ethisk Interesse, og den vil derfor i høi Grad glæde ja ligesom overbevise en Ethiker, der i Kamp for sin Livsanskuelse stolt peger paa et saadant Phænomen, som paa sin Seier, i stille, inderlig Taknemmelighed kalder en saadan Skuespillerinde sin almægtige Allierede, fordi hun, bedre end han, og netop paa eet af de allerfarligste Puncter beviser hans Theori. Den Metamorphose derimod, om hvilken vi have talt, er Potensationens, eller den er en intensivere og intensivere Tilbagevenden til sit Første. Denne Metamorphose vil absolut beskæftige en Æsthetiker, thi Potensationens Dialektik er netop den æsthetisk-metaphysiske Dialektik. Lykkeligere end Archimedes vil han dithyrambisk raabe »heureka«, idet han peger paa Phænomenet; beruset i Beundring og dog ædru i dialektisk Besindighed vil han kun have Øie for dette Eneste, og forstaae det som sit Kald at skaffe Plads, for at det Vidunderlige kan blive seet og beundret just som saadant. - Continuerlighedens Metamorphose vil i Aarenes Løb ligeligt udbrede sig over det væsenlige Omfang af Opgaver indenfor Qvindelighedens Idee; Potensationens vil i Aarenes Løb forholde sig intensivere og intensivere til den samme Idee, 
hvilken vel at mærke, æsthetisk forstaaet, er sensu eminentissimo Qvindelighedens Idee. Vil man om den Skuespillerinde, der svarer til Continuerlighedens Metamorphose, sige, at hun, i Idealitetens Forstand, vel bliver ældre, men ikke ældre i Timelighedens Forstand; saa maa man om den anden sige, at hun bliver yngre. Men om dem begge maa der siges, at Tiden ingen Magt har over dem. Der er nemlig een Modstand mod Aarenes Magt, det er Perfectibiliteten, den udfolder sig just i Aarene; og der er en anden Modstand mod Aarenes Magt, det er Potensationen, den bliver netop aabenbar i Aarene. Begge Phænomener ere væsenligen Sjeldenheder, og begge have de det tilfælles, at de med hvert Aar blive sjeldnere. Netop fordi de ere dialektisk sammensatte, vil ogsaa deres Existens Aar for Aar blive dialektisk; hvert Aar vil gjøre Forsøget paa at bevise sin Sætning om Aarenes Magt, men Perfectibiliteten og Potensationen vil seierrigt modbevise Aarenes Sætning. Dette giver atter absolut Ro i Tilskueren, thi det 17de Aars Ungdommelighed er dog skrøbelig, men Perfectibiliteten og Potensationen er den absolute Tilforladelighed.

Maatte det ved denne lille Artikel være lykkedes mig, at bidrage Noget til at gjøre det indlysende, hvor betrygget, trods Aarene, den væsenlige Skuespillerindes Fremtid er, skulde det være mig en kjær Tilfredsstillelse, saa meget mere, som jeg er forvisset om, at der paa saa mange Maader er Misforstand nok i Forhold til den rette Opfattelse af en Skuespillerindes Fremtid, idet den samme Misforstaaelse, der misforstaaet og uæsthetisk overvurderer Begyndelsen, misforstaaet og uæsthetisk seer feil af det Senere, eller rettere af det Høieste.

Sommeren 1847.

Inter et Inter.

KIERKEGAARD, Søren. Krisen og en Krise i en Skuespillerindes Liv.. In.: Søren Kierkegaards Skrifter. Band 14. København: Søren Kierkegaard Forskningscenteret, 2014. 


\section{A crise e uma crise na vida de uma atriz}

Soren Kierkegaard

Tradução do dinamarquês:

Lucas Piccinin Lazzaretti

\section{I}

A ideia de ser uma atriz, isto é, alguém de destaque, provavelmente desperta de imediato na maioria das pessoas a ideia de uma condição de vida tão encantadora e excelente que os espinhos são com frequência esquecidos: o incrível número de trivialidades, todas as injustiças e mal-entendidos contra os quais, mesmo no momento mais essencial, uma atriz pode ter de lutar.

Imaginemos a condição mais favorável possível; imaginemos uma atriz que possui tudo que é necessário para ser incondicionalmente destacada, imaginemos que ganha o reconhecimento da admiração e que tem a sorte (o que, sem dúvida, representa um êxito tremendo) de não ser o objeto de perseguição de pessoas odiosas: então ela vive, ano após ano, o afortunado objeto de uma admiração apreciativa sempre renovável. Parece glorioso, parece ser mesmo algo; mas quando se olha mais de perto e se vê a moeda com que essa admiração apreciativa é paga, se vê a pobre essência dos gastos triviais que no mundo crítico teatral constituem o fundo ad usus publicos [para o uso público] (e é a partir desse fundo que, é claro, a admiração apreciativa é paga), podendo muito bem ser possível que mesmo essa circunstância afortunada seja, para uma atriz, bastante vulgar e miserável. - Se é mesmo como dizem, que o guarda-roupas do Teatro Real deve ser muito caro e valioso, então não há dúvida: o guarda-roupas dos críticos jornalísticos é terrivelmente pobre.

Mas continuemos. A artista admirada segue vivendo anos após ano. Como nas famílias burguesas, sabe com antecedência exatamente o que deve ter para jantar a cada dia, assim como sabe com antecedência exatamente quais são os emolumentos de cada temporada. Duas a três vezes por semana ela será elogiada e admirada, tratada com distinção; já no decurso dos primeiros três meses ela será mais de uma vez analisada pela soma de frases críticas em resenhas de jornais - e por expressões retomadas [Vendinger], como com especial ênfase poderiam ser chamadas, já que estas retornam [vende tilbage] pelo mesmo caminho. Uma ou duas vezes, em um bom ano três vezes, será louvada por um sujeito decaído ou por um pretenso poeta; seu retrato será pintado a cada exposição de arte; ela será litografada e, se a fortuna muito a favorecer, seu retrato estará em lenços de 
bolso e nas copas de chapéus. Ela, enquanto mulher, é zelosa com seu nome - enquanto mulher ela sabe que seu nome está nos lábios de todos, mesmo quando secam a boca com o lenço de bolso, ela sabe que é o objeto de todas as admiradas conversas, mesmo daqueles que estão em extrema agonia para ter algo sobre o que falar. Assim ela vive ano após ano. Parece glorioso, parece ser mesmo algo, mas uma vez que agora ela, no mais nobre sentido, vive do alimento desta admiração, encontra incentivo por meio dela, fortalecendo-se e inflamando-se com isso a cada novo esforço, então mesmo a pessoa mais talentosa, sobretudo por ser mulher, pode ver-se desanimada após uma observação de real apreciação: nesse instante ela saberá o que ela naturalmente já havia sentido, o quão vazio isto tudo é e como é injusto invejá-la por esta glória onerosa.

Enquanto isso passam-se os anos, embora não muitos nesses tempos de curiosidade e impaciência, e logo chegam as conversas de que ela começa a envelhecer, e então - sim, vivemos realmente em países cristãos, mas assim como muitas vezes vemos exemplos suficientes de bestialidade estética, ainda estamos longe de poder afirmar que o desejo canibal dos sacrifícios humanos tenha caído em desuso na cristandade. O mesmo profundo modismo que interruptamente toca o tambor da trivialidade em seu louvor, honrando-a graciosamente com seus címbalos, este mesmo modismo agora se entedia com sua adorada artista, quer que ela vá embora, não quer mais vê-la, e ela deve agradecer a Deus se este não quiser matá-la; o mesmo modismo obteve um novo ídolo de 16 anos e, em homenagem a ela, o antigo ídolo tem de sentir toda a desgraça de sua trivialidade - pois esta é a grande dificuldade que está associada à idolatria, que é quase impensável despedir-se com graça dessa estima. Ou, se este não é o caso, ou se não é tão gritante quanto aquele ora apresentado, então às vezes algo que parece muito melhor acontece, mas, ao fim, este algo é igualmente ruim. A trivialidade está, por força do passado, em um impulso tão bom para com a admiração que é permitido à adorada avançar para uma velocidade final ainda por um tempo mesmo depois de ela, conforme dizem, ter envelhecido. Aparentemente, não há mudanças nas expressões da trivialidade sobre a artista adorada; no entanto, parece surgir uma traiçoeira incerteza de que o elogio de Rosiflengius ${ }^{6}$ possa mostrar-se tão vago em benefício da artista a ponto de soar estranho que ele continue galantemente a dizer o mesmo. Mas ser galante com uma artista é o mais alto grau de insolência, uma pegajosa impertinência e a mais repugnante intrusão. Qualquer pessoa que é algo e é essencialmente algo tem a necessidade eo ipso de ser reconhecida por esta determinação específica [Bestemte], nem mais nem menos. - Se é assim como dizem, que o teatro é um santuário: a profanação ao menos não está longe. Quão oneroso e embaraçoso, aos 16 anos, é suportar na forma de crítica de arte o ajoelhar-se hipócrita e as declarações de amor de velhos

6 Referência ao personagem criado pelo escritor dinamarquês Ludvig Holberg, apresentado na comédia Det Lykkelige Skibrudd (O Naufrágio Feliz), de 1731, o qual caracterizava-se por ser um poeta profissional de ocasião que compunha louvores e elogios apenas mediante pagamento. Trata-se de uma caracterização da hipocrisia no âmbito das artes, de modo que o personagem acaba sendo punido ao fim da peça. 
carecas ou de resenhistas de sagacidade duvidosa; quão amargo, mais tarde, é suportar a arrogância da galanteria!

Mas por que agora esta desumanidade, que, no entanto, causa tanta injustiça, e até mesmo, crueldade, para com as mulheres a serviço da arte? Por que razão, senão porque a formação estética é tão rara entre as pessoas? A maior parte da crítica de arte das pessoas, com relação às mulheres, tem categorias e maneiras de pensar [Tankegang] essencialmente idênticas às de qualquer assistente de açougueiro, oficial da guarda ou balconista, que fala entusiasmado sobre uma amaldiçoadamente linda e diabolicamente atrevida garota de 18 anos. Esses 18 anos, essa amaldiçoada beleza e esse atrevimento diabólico, isto é a crítica de arte - e também sua bestialidade. Por outro lado, lá onde, esteticamente falando, o interesse realmente começa, lá onde o interior com alegria e intensidade revela-se na metamorfose: lá o número de pessoas diminui. Se alguém continua a admirá-la, então pensam que ou se está sendo galante, ou se está sendo gentil; pois quando ela tem apenas 30 anos ela está basicamente perdue ${ }^{7}$ !

Seria realmente desejável, para o bem das próprias pessoas, que elas não fossem excluídas ou se não excluíssem a si mesmas dos prazeres mais importantes, que este preconceito fosse de fato erradicado. E é realmente um preconceito, sim, um preconceito bestial, pois não é o caso que uma mulher torna-se atriz em seu $18^{\circ}$ ano; se for o caso de tornar-se, isto acontecerá em seu $30^{\circ}$ ano ou mais tarde, pois atuar em comédias aos 18 anos é visto como algo esteticamente questionável. Começar a admiração pelo segundo período de desenvolvimento está tão longe de ser galante que o oposto é facilmente coquetismo: admirar uma pequena donzela de 16 anos. Eu realmente não acredito que um esteta essencialmente formado pudesse se convencer a fazer de uma atriz de 16 anos o objeto de uma crítica, especialmente se ela fosse muito bonita, etc.; ele indubitavelmente perhorrescere [rejeitaria] esta ambiguidade. É verdade que a garota que produziu um furor com 18 anos muitas vezes não se perpetua. Seja como for, neste caso ela não foi essencialmente uma atriz, já que fez um furor no palco no mesmo sentido que uma jovem pode criar um furor no clube de campo [Venskabelige $]^{8}$ por um ou dois invernos. Por outro lado, também é verdade que quando a metamorfose é bem-sucedida, não se pode falar em galanteria; pois só então a admiração está, no sentido estético, em seu profundo direito.

Veja, muito foi feito no teatro para garantir o futuro das atrizes: acredito que também seria muito benéfico livrar-se completamente dessa superstição totalmente inestética relativa aos 18 anos a fim de tornar óbvio que a decisão importante ocorreria muito mais tarde - isso também seria uma garantia para o futuro das atrizes. E o assunto em si não tem

7 Perdida, no original em francês.

8 Kierkegaard faz uma referência ao clube fundado em $1783 \mathrm{em}$ Copenhagen que tinha por nome Det Venskabelige Selskabe, o qual servia como um importante ponto de encontro social e onde se realizavam bailes e concertos durante o inverno e também dispunha de um espaço onde os membros podiam ler jornais e revistas, bem como divertir-se com jogos de carta e especialmente com o bilhar. 
apenas um interesse estético, mas também um alto grau de interesse psicológico, portanto me surpreende que isto não seja frequentemente tornado um objeto de consideração. $\mathrm{O}$ interessante é, com a ajuda da psicologia, ser capaz, de forma puramente estética, de estimar a metamorfose, ou de ser capaz de explicá-la uma vez que tenha ocorrido.

Um pequeno artigo em um jornal, no entanto, não é o lugar adequado para uma investigação mais detalhada que analisa sistematicamente [gjennemgaaer] várias ocorrências. Aqui, portanto, eu apenas tento puramente descrever psicológica e esteticamente uma única metamorfose, certamente difícil, mas por isso mesmo bela e significativa. Quanto mais é dado e quanto mais é inserido no primeiro extrato [Udtrak], tanto mais difícil é obter um novo extrato, e quanto mais um público fundamentalmente inestético, idólatra e ruidoso tenha conhecimento do primeiro extrato, tanto mais facilmente este público é transformado em uma ansiosa, desconfiada e até mesmo sombria oposição para com a metamorfose. Uma atriz que nunca teve a fortuna de ter a posse definitiva daquilo que encanta e aprisiona o público inestético em tão alto grau pode, talvez, em compensação por isto, ter a fortuna de fazer sua metamorfose em completo silêncio [Stilhed] ${ }^{9}$. Isto também é belo, e o é porque ocorre tão silenciosamente, mas também é mais fácil, precisamente porque a transformação silenciosa preliminar à metamorfose não é perseguida pela curiosidade e não é perturbada por mal-entendidos, mas se evade dos arroubos e caprichos do público. O público é, portanto, estranho; quando o tempo, no decurso de 10 anos, por exemplo, tomou a liberdade de tornar a declarada favorita 10 anos mais velha, o público então fica zangado - mas com a favorita.

\section{II}

Penso em uma atriz no começo de sua carreira, na felicidade inicial de sua juventude, no instante em que pela primeira vez apareceu e pela primeira vez produziu uma grande felicidade. Sobre isto eu posso com direito falar esteticamente e ter a alegria de fazê-lo, pois esta análise é ideal, já que não lida com uma atriz real de 16 anos que é uma contemporânea. Também por outra razão é esteticamente apropriado retratar essa primeira juventude; pois o objeto real da análise é a metamorfose, de modo que nem no pensamento

9 O termo empregado por Kierkegaard, Stilhed, carrega tanto o sentido de "silêncio" quanto o sentido de "permanência" ou "quietude". Há aqui uma duplicidade de significados proposta pelas veredas conceituais kierkegaardianas: por um lado, o "silêncio" é a oposição evidente ao "falatório" (at snak.ke), este associado à linguagem vazia e à manifestação da massificação; por outro lado, o sentido de "permanência" é oposto ao sentido de certo "devir", neste texto em especial fazendo referência a uma diferenciação entre um falso devir, que ocorreria em relação à exterioridade e, portanto, ao público, e um "devir autêntico", que aconteceria precisamente na quietude de certa permanência. É preciso lembrar que este ensaio é a tentativa kierkegaardiana de abordar uma temática estética sob a égide de conceitos fornecidos pelo ponto de vista religioso. 
do ensaio sou contemporâneo desta juventude. A descrição do primeiro período é para organizar, é uma recordação poética e filosófica completamente sem pesar; não se debruça sobre este primeiro período, pelo contrário: deste se afasta apressadamente como sempre se faz quando se recorre ao mais elevado, e o autor está esteticamente convencido de que a metamorfose é o mais elevado.

Ela estreia em seu $17^{\circ}$ ano. Ela possui algo - sim, o que ela possui é muito difícil de determinar apenas porque é algo indeterminado, que, no entanto, onipotentemente se faz sentir e é incondicionalmente obedecido. A pessoa mais rabugenta e entediante não pode ajudá-lo a resistir, ele deve obedecer; um matemático não pode ajudá-lo ao mostrar-se relutante dizendo "o que isto demonstra?", ele deve obedecer, ele está no fundo convencido: ergo, ela possui - sim, o que ela possui é muito difícil de determinar apenas porque é algo indeterminado. Que estranho! Usualmente é possível afirmar com precisão o que uma pessoa possui, e, quando isto é possível, pode-se ver até que ponto chega - com aquilo que possui. E, por outro lado, uma jovem atriz que possui esta posse indeterminável faz com que agora morram de fome todos os proprietários!

Esta posse indeterminada está, no entanto, um pouco mais perto de ser determinada: felicidade [Lykkee]; ela está em posse da felicidade ${ }^{10}$. Felicidade não significa que ela é afortunada por ter bons amigos e contatos importantes, ou por ter a fortuna de ter sido aceita no teatro em tão bons termos, ou tão afortunada que o diretor e os críticos estejam interessados nela; não, a felicidade significa aqui o que César falou para o capitão quando lhe disse: você carrega a César - e sua felicidade ${ }^{11}$. Sim, se não fosse para desafiar sua felicidade, ela poderia ousar pôr nos cartazes todas as noites em que atua: Senhorita Fulana e sua felicidade - nesse grau ela está em posse de sua felicidade. Ela tem a felicidade consigo, e já é muito que agrade a essa força onipotente servir como guia de uma jovem; não, a felicidade mesma está a seu dispor. E como não se pode dizer que ela está em posse [ $i$ Besiddelse] da felicidade, deve ser, então, porque ela está possuída [er som besat af pela felicidade ${ }^{12}$ - a ponto de esta segui-la onde quer que vá, em todas as suas ações, no menor movimento de sua mão, em cada canto do olho, em cada balanço de cabeça,

10 Kierkegaard emprega a palavra Lykke, que tanto pode significar o sentimento de felicidade quanto pode significar uma boa sorte ou um destino favorável. Optamos por traduzir por "felicidade" a fim de manter precisamente esta ambiguidade que é tanto o elemento de exterioridade - um destino favorável - quanto um elemento de interioridade - a percepção da felicidade.

11 Kierkegaard faz menção, de forma livre, à historieta que conta Plutarco em sua biografia de César sobre a travessia que o ditador romano, disfarçado de escravo, teria feito em um pequeno barco. Em meio a uma tempestade, César teria se voltado para o piloto dizendo, "Meu amigo, coragem, vamos adiante sem temor, pois levas César e a fortuna de César neste barco". Cf. PLUTARCO. Vidas Paralelas. Trad. Gilson César Cardoso. São Paulo: Paumape, 1991-1992.

12 Kierkegaard faz um jogo entre o estar "em posse" (i Besiddelse), e o estar "possuído por" (er som besat af), valendo-se para tanto de uma noção de posse ambígua que tanto denota o aspecto de propriedade quanto denota uma condição ou uma situação. 
em cada giro do corpo, no andar, na voz, nos gestos, a felicidade a segue de tal modo a não permitir que nem por um segundo o crítico de arte veja o que ela faria sem felicidade, mesmo que ele já esteja esteticamente ciente de que o melhor de tudo isso, no entanto, não pertence a ela em nenhum sentido.

Sua posse indeterminada, para determiná-la um pouco mais, significa: juventude [Ungdommelighed ${ }^{13}$. Isto não significa a estatística de que exatamente uma semana atrás, na segunda-feira, ela completou 16 anos, nem que ela é uma jovem que em função de sua beleza e de outras coisas é apresentada à vista [Skue] e por isso é inadequadamente chamada de atriz. [Skuespillerinde]; não, sua juventude é novamente uma riqueza indeterminada. Em primeiro lugar, é o jogo vital de poder, o qual também pode ser chamado de frescor vital e rica inquietação da juventude, sobre o qual sempre e involuntariamente se fala com parcialidade, como quando dizem que a criança afortunadamente talentosa é a inquietação na família. A inquietação, entendida como o ruído da finitude, rapidamente pode satisfazer, mas a inquietação no sentido do entendimento, a inquietação do infinito, a originalidade feliz e vivaz que, rejuvenescendo, refrescando e curando, agita a água ${ }^{14}$, esta é uma enorme raridade e, neste sentido, ela é inquietante. Contudo, essa inquietação significa algo e algo muito grande - significa o primeiro frenesi de um gênio essencial. E essa inquietação não significa nada acidental [Tilfceldigt], não significa que ela não possa ficar parada, pelo contrário, significa que mesmo quando está parada é possível sentir sua inquietação, mas, note-se, em repouso. Isto não significa que ela vem correndo para o palco, ao contrário, significa que enquanto ela simplesmente se move tem-se a percepção da velocidade do infinito. Isto não significa que ela fala tão rápido que não é possível acompanhá-la, pelo contrário, significa que quando ela fala lentamente é possível sentir a expiração e a inspiração. Esta inquietação não significa que ela deva rapidamente se cansar, mas justamente o oposto: revela uma perseverança elementar, como aquela do vento e do som da natureza; ela revela que a malandragem é inesgotavelmente rica, que ela trai-se por possuir muito mais; ela revela que seu coquetismo (e sem o coquetismo essa figura é impensável) não é outra coisa senão uma consciência contente, inocentemente alegre e triunfante de sua indescritível felicidade. Isto não é, portanto, propriamente coquetismo, mas um incentivo a mais para o espectador; garante a confiança do todo e garante a exuberância com absoluta segurança.

Pode-se supor que ter por um lado confiança e por outro lado malandragem, vivacidade, felicidade e juventude são determinações completamente díspares que não pertencem

13 O termo empregado por Kierkegaard tem o sentido de uma plenitude da primeira idade e, ao mesmo tempo, visa indicar o movimento que chega a essa plenitude. Em dinamarquês, "juventude" ou "mocidade" pode ser expressa com o termo ungdom, esta compreendendo o período e não o movimento antes indicado. Ao utilizar Ungdommelighed o filósofo quer apontar precisamente esta dupla condição de movimento e permanência. Optamos aqui por traduzir por "juventude" para evitar confusões que poderiam advir de escolhas tais como "jovialidade" ou "mocidade".

14 A referência à agitação das águas relaciona-se com João 5:2-9. 
ao mesmo grupo. Contudo, está longe de ser esse o caso; elas pertencem absolutamente ao mesmo grupo. Se a malandragem e a vivacidade não são incondicionalmente garantidas por uma confiança absoluta que aqui é suficiente, tanto para ela quanto para uma dúzia de outros, então a apresentação é eo ipso lamentável e o desfrute é essencialmente ausente. A inseparabilidade também pode ser reconhecida pela correspondência bastante consistente ao colocar juntas confiabilidade e malandragem, como quando um homem velho, mas ainda vivaz, com todo o amor por uma jovem malandra diz: esta é com certeza uma moça confiável, ele não está dizendo que ela é malandra, mas que ela é confiável, e ainda assim, ao fazê-lo, ele diz que ela é malandra, e isso não é sua invenção, mas ela extrai dele essa afirmação com malandragem.

Pode-se supor que ter por um lado exuberância e por outro lado a certeza absoluta de garantia são determinações díspares que não pertencem ao mesmo grupo e apenas um estúpido poderia querer pô-las juntamente; e, no entanto, elas são inseparáveis e o componente dialético desta composição. É verdade sobre tudo o que é determinação natural e, como tal, algo singular [Enkelt] e inequívoco, que isto deve ser absolutamente seguro. Aquilo que é composto pode ter algo que se perde, mas o que é singular é imediato, deve ser absoluto ou, o que é o mesmo, quando é, é absoluto. Uma pequena exuberância é eo ipso rejeitada como algo indecoroso. A adequada exuberância, portanto, parece em primeiro lugar, precisamente por sua garantia de segurança absoluta, um efeito de calma para o espectador, porém escapando à atenção da maioria das pessoas, às quais parece que a exuberância é estimulante, o que se aplica apenas à exuberância falsa ou para a pouca exuberância. Tomemos um exemplo do cômico imediato, do humor ${ }^{15}$. Quando em uma noite vê-se Rosenkilde ${ }^{16}$ entrar em cena como se viesse direto do infinito e com ímpeto, possuído por todos os espíritos do humor, involuntariamente dizemos a nós mesmos à primeira vista, "bem, hoje à noite ele está uma tempestade" ${ }^{17}$ : então nos sentimos indescritivelmente acalmados. Respiramos para realmente relaxar; sentamo-nos confortavelmente como quem pretende ficar na mesma posição por muito tempo; quase nos arrependemos

15 O trecho no original consta: "af den umiddelbare Comik, af Lune.”. O "cômico imediato" ou o "imediatamente cômico", então associado com o "humor" [Lune] faz referência à influência e ao debate que Kierkegaard travava com alguns estetas de sua época acerca das teorias sobre os gêneros dramáticos, especialmente considerando-se aqui o alvo constante que é Johan Ludvig Heiberg, poeta, filósofo e importante nome do cenário literário dinamarquês que, por sinal, era casado com Johanne Luise Heiberg, a personagem/objeto do ensaio.

16 Christian Niemann Rosenkilde (1786-1861) foi um ator dinamarquês empregado a partir de 1815 pelo Teatro Real, onde atingiu grande sucesso e prestígio ao interpretar papéis cômicos nas comédias de Ludvig Holberg e nas comédias de J. L. Heiberg. Kierkegaard havia iniciado a escrita de um ensaio em homenagem ao ator, em 1847, intitulado Rosenkilde como Hummer, mas esse ensaio não foi concluído. Para conferir o texto, ver os Diários na entrada [VIII.2 B 72].

17 No original consta: "naa, iaften har han en ordenlig Storm". Trata-se de uma expressão para alguém que está profundamente bêbado ou que se encontra tomado fortemente por paixões ou, ainda, que está profundamente entusiasmado. 
de não ter levado comida, pois a confiança e a segurança que acalma é tão grande que quase nos esquecemos que é só questão de uma hora no teatro. Enquanto rimos e rimos, e em silêncio regozijamo-nos com a exuberância humorística, estamos continuamente calmos, indescritivelmente persuadidos e com o acalanto da garantia absoluta, porque aquele humor produz uma só impressão: isso pode durar o quanto for. E, por outro lado, se um comediante imediato, antes de tudo, não acalma absolutamente, se houver uma migalha de angústia no espectador sobre quanto se estenderá a comédia: então o prazer está essencialmente perdido. Diz-se que um comediante deve ser capaz de fazer os espectadores rirem, mas talvez se deva dizer que ele deve, em primeiro lugar, ser capaz de acalmá-los, e então o riso vem por si próprio; pois o riso genuíno, este riso vindo do fundo do coração, não irrompe por um estímulo, mas apenas em função do acalmar-se. Assim é também com a exuberância: esta deve, em primeiro lugar e acima de tudo, acalmar-se com absoluta garantia, isto é: se está verdadeiramente presente em uma atriz, então isto deve parecer ser absolutamente apaziguador. É nesta calma, induzida pela calma absoluta e pela garantia, que o espectador por sua vez se rende - em exuberância. Veja, aqui novamente: exuberância e calma parecem uma composição estranha, e dizer que a exuberância é confiável é um discurso estranho; e, no entanto, é a correta e única nova expressão para a malandragem, pois a exuberância acalentadora é apenas uma malandragem.

Sua posse indeterminada, para se estar mais perto de determiná-la, significa ainda mais: plenitude da alma [Sjalfuldhed], que na atmosfera da paixão imediata ela está em concordância com ideias e pensamentos; que sua interioridade irrefletida está essencialmente de acordo com a idealidade; que todo toque de pensamento ou ideia faz soar uma nota e faz soar uma reverberação completa; que ela é uma sensibilidade específica e original. Assim, ela confia com toda sua alma nas palavras do autor; mas para consigo mesma ela confia em algo mais que pode ser chamado propriamente de ressonância [Klangen] em relação à réplica, e de harmonia [Samklangen] em relação a toda figura [Skikkeelsen]. Ela não simplesmente toma as palavras corretamente da boca do autor, mas devolve-as de tal forma que em seu cossoar de malandragem [Skjalmeriets Medlyden], em seu coconhecimento da engenhosidade [Snildets Medviden] é como se dissesse: você pode fazer o mesmo que eu faço?

Sua posse indeterminada significa, finalmente: que ela está em uma relação adequada para com a tensão cênica. Qualquer tensão pode - esta é a dialética da própria dialética - trabalhar de maneira dupla; ela pode tornar o esforço manifesto, mas também pode fazer o contrário; por ocultar o esforço, e não apenas ocultá-lo, mas continuamente convertê-lo, transformá-lo e explicá-lo em leveza. A leveza é então invisível no esforço de tensão, mas isto não é visto, não é conhecido, apenas a leveza é revelada. Um peso pode pressionar algo para baixo, mas pode também inversamente esconder que está pressionando algo para baixo e então expressar a pressão pelo oposto, levantando algo. Fala-se coloquialmente em fazer-se leve por lançar fora os fardos, e essa consideração é a base de todas as visões-de-vida [Livsanskuelser] triviais. No sentido mais elevado, poético e filosófico, é o oposto: tornamo-nos leves com a ajuda de - peso, elevamo-nos altos e livres com a ajuda de - pressão. Os corpos celestes, dessa maneira, flutuam com a ajuda de um grande peso; 
o pássaro voa com a ajuda de um grande peso; o leve pairar da fé se dá pela ajuda de um peso enorme; a mais crescente elevação da esperança se dá precisamente por ajuda da dificuldade e da pressão das tribulações. Mas a ilusão cênica e o peso de todos os olhos são uma pressão enorme colocada sobre uma pessoa; portanto, onde essa feliz relação está faltando, nem ao menos a capacidade adquirida em alto nível será suficientemente capaz de esconder o peso do fardo, mas onde há essa feliz relação, o peso do fardo se transforma em leveza. Assim o é com a jovem atriz; na tensão da cena ela está em seu elemento, precisamente ali ela é leve como um pássaro, de tal modo que o peso lhe dá leveza e a pressão lhe dá o impulso para uma elevação. Não há traço de angústia; nos bastidores ela talvez esteja angustiada, mas no palco ela é feliz e leve como um pássaro que ganhou sua liberdade, pois é agora, sob pressão, que ela é livre e ganhou sua liberdade. Aquilo que em casa, no momento de estudo, aquilo que nos bastidores parece angústia, isto não é impotência, mas o contrário, é elasticidade, que a angustia porque ela não tem peso sobre si; na tensão teatral essa angústia transforma-se em potenciação [Potensation]. É de todo uma consideração muito limitada assumir que um artista e uma artista não devam angustiar-se e, acima de tudo, que é um medíocre sinal do grande artista que ele não esteja angustiado. Quanto mais força ele tem, maior é a sua angústia, contanto que ele esteja do lado de fora da tensão que corresponde exatamente aos seus poderes. Se em uma personificação a força da natureza que suporta os corpos celestes é pensada fora de sua tarefa, na esperança de assim a superar: então esta estaria em uma angústia mortal, e apenas no instante em que fora sobrecarregada seria despreocupada e leve. Portanto, é um dos maiores sofrimentos para uma pessoa ter uma grande elasticidade em relação à tensão do pequeno mundo em que vive, pois esse infeliz nunca se sentirá muito livre só porque não pode ganhar peso suficiente sobre si mesmo. O caso é apenas que a angústia acerta de forma absolutamente correta, de tal forma que em relação ao artista cênico ela está sempre fora do palco, nunca no palco, como sói acontecer com aquele que é angustiado fora do palco.

Essa posse determinada é naturalmente fácil de indicar. Ela não só tem uma graça natural, mas também é bem formada; como uma força auxiliar, ela tem o máximo que uma dançarina faz para ter. Sua dicção é correta e precisa, sua voz não é mal-usada, mas é cultivada, sem ser estridente, sem um hiato ela completa e distintamente determina a palavra, a qual não mantém consigo nem para si, mas tampouco a projeta sem controle; ela articula muito bem, mesmo quando sussurra; ela sabe usar a voz e, acima de tudo - o que felizmente beneficia as suas pré-qualificações -, sabe como usá-la nos insignificantes e descontraídos desvios das réplicas conversacionais.

Ela então faz a sua estreia aos 17 anos. Sua performance é, naturalmente, um triunfo; e ao mesmo tempo sua vida transforma-se em uma questão nacional. Como a filha do regimento é considerada a filha de todo regimento ${ }^{18}$, então ela torna-se a filha da

18 Trata-se de uma referência à ópera cômica em dois atos, A filha do Regimento [La fille du régiment], de Gaetano Donizetti, com libreto de Georges Henri Vernoy de Saint-Georges e Jean-François Bayard. 
nação. A mera primeira visão dela é suficiente para garantir a todos o quão difícil é encontrar um exemplo do afortunado talento feminino em cada geração. Torna-se, assim, um dever nacional admirar e uma preocupação comum cuidar desta rara planta, ai!, e se não pode ser chamado um dever, então torna-se, enquanto uma questão de fraqueza humana, um interesse de curiosidade ver quanto tempo ela pode durar. Sim, a alegria humana em relação à raridade é estranha, quase no primeiro e mais alto instante de alegria o assassinato da curiosidade começa. Não se trata de ciúme, longe disso; é um tipo de confusão na admiração, que por assim dizer não sabe o que fazer de tanto júbilo até que, por certo, no primeiro ano desenvolve essa tensão assassina que, por pura admiração, admira quase que de forma suspeita.

Para mais uma vez relembrar o que foi frequentemente apresentado: se um verdadeiro esteta vivesse naquele tempo e este fosse encorajado a tentar avaliar criticamente essa atriz ou sua performance, então ele provavelmente diria: não, o tempo dela ainda não veio realmente.

\section{III}

Já se passaram 14 anos, ela está agora com 31. Ao longo desses anos ela tem sido objeto daquele sempre admirável reconhecimento. Deixe-me sugerir essa passagem do tempo usando este espaço para algumas considerações. Não nos deixemos enganar, com base em aparências, pela soma total de acidentes e assim não nos deixemos invejar injustamente sua admiração; consideremos, pelo contrário, quanta confusão interfere com a constante revisão desse trivial reconhecimento; e, acima de tudo, não nos esqueçamos o que implica e o que significa que nos últimos 14 anos tenha se tornado um hábito para os seus contemporâneos admirá-la e, se queremos considerar corretamente, não esqueçamos, de forma injusta para com ela, de subtrair isto da pressuposta glória da admiração. Ah, quão raramente se encontra uma pessoa, para não falar de uma geração [Samtid], que não recaia na fraude do hábito, então mesmo que a expressão não tenha mudado, esta expressão inalterada tornou-se no entanto outra coisa através do hábito, e no entanto esta igualdade textual agora soa demasiado fraca, demasiado mecânica, demasiado monótona, ainda que se diga a mesma coisa. Ah, no mundo muito se fala sobre sedutores e seduções: mas quantos são aqueles que enganam-se a si mesmos por meio do hábito, de forma a parecerem inalterados ainda que estejam emaciados em sua humanidade interior [indvortes Menneske]; e assim amam as mesmas pessoas, amam-nas, mas sem força e debilmente; e assim usam as mesmas sentidas expressões, mas fracamente, impotentemente e tão desalmadamente [afsjclet]. Se um rei quisesse visitar uma pobre família - sim, esta se sentiria excelente, orgulhosa, quase esmagada por sua própria felicidade; mas se a Majestade quisesse visitar a mesma família todos os dias, quanto tempo demoraria até que o rei tivesse de fazer um esforço para encontrar o sentido pelo qual visitava a família, que permaneceu inalterada e, no entanto, continuou por hábito a dizer: nós agradecemos pela grande honra. De todos 
os sofistas, o tempo é o mais perigoso, de todos os perigosos sofistas, o hábito é o mais astuto. Que alguém mude pouco a pouco ao longo dos anos já é algo difícil de perceber; mas a fraude do hábito é que a pessoa é a mesma, inalterada, que diz a mesma coisa, inalterada, e ao mesmo tempo está mudada e ainda assim o diz, mudada.

Precisamente por esta razão, toda inútil [unyttige] verdade, isto é, as servas altruístas [uegennyttige] da verdade, cuja vida é uma luta com os sofismas da existência [Tilvarelsens Sophismer], cuja preocupação não é como obter o melhor para si mesmas, mas como verdadeiramente ganhar a verdade e na verdade beneficiar as pessoas: elas já sabem como fazer uso das ilusões - para testar as pessoas. Quando, assim, um homem distinto vive muito recluso, quando aparece apenas raramente, as pessoas não são mal-acostumadas por vê-lo. Contudo, ali se desenvolve um excelente, si placet [se quiser], expediente de ilusão: que este homem distinto deva ser alguém extraordinário; e é por que as pessoas sabem avaliar as suas excelentes qualidades?; ah, não - é porque o veem tão raramente que essa visão rara produz um efeito fantástico. Que isto pode ser feito é uma experiência antiga; o método, magistralmente expresso por Shakespeare no encargo do Henrique IV ao Príncipe Henrique ${ }^{19}$, tem sido usado por uma numerosa multidão de reis, imperadores, clérigos, jesuítas, diplomatas, cabeças inteligentes, etc., entre os quais sem dúvida havia muitos homens excelentes, muitos que queriam servir à verdade, mas todos concordaram que trabalhariam com a ajuda de uma ilusão, fosse para beneficiarem-se eles mesmos, certificando-se do estupor da multidão, ou também porque pensavam sagazmente em obter para a verdade uma disseminação mais ampla com a ajuda de - uma ilusão. Contudo, os servos incondicionalmente altruístas da verdade sempre tiveram a habilidade de estar presentes entre as pessoas, nunca brincaram de esconde-esconde com a multidão a fim de recrear-se com um jogo de adivinhação [Forundringslegen] quando, em raras ocasiões, acabam por ser o objeto surpreendente de espanto $^{20}$, pelo contrário, eles sempre mostraram-se em roupas do dia a dia, vivendo com o homem comum, falando pelas ruas e vielas, renunciando a toda estima - pois quando a multidão vê um homem todos os dias, a multidão pensa assim: é só isso? Ah, sim, “mundus vult decipi" [o mundo quer ser enganado], mas as testemunhas altruístas da verdade nunca quiseram entrar nessa ilusão, nunca quiseram ir com a multidão para a parte seguinte:

19 Trata-se de uma referência à peça histórica Henrique IV de Shakespeare, especificamente tratando-se de uma passagem presente na segunda cena do terceiro ato (versos 39-59), quando o rei Henrique ensina ao seu filho, o príncipe Henrique de Gales, sobre o expediente da ausência. Cf. SHAKESPEARE, William. King Henry the Fourth, I, III, 2, 39-59.

20 Kierkegaard faz um jogo com a palavra forundring, que tem o sentido de "espanto" e que está na raiz do termo "jogo de espanto" (Forundringslegen). Trata-se de um jogo em que uma pessoa vendada se senta em um banquinho no centro de um círculo enquanto outro participante anda e pergunta de forma discreta aos integrantes do círculo o que eles pensam sobre a pessoa do centro. Ao ouvir as respostas o jogador vendado tem de adivinhar quem emitiu cada juízo sobre sua pessoa com base em sua intuição. Em decorrência da natureza do jogo, o termo "sentado no banco admirador" [at sidde på forundrings stolen] tem o sentido de "estar exposto" à crítica alheia e aos olhos de todos. 
"decipiatur ergo" [então engane]; pelo contrário, eles enganaram fazendo o oposto, isto é, eles julgaram o mundo por parecerem insignificantes.

Se um autor que não tem um fundo substancial de ideias e que também não é muito industrioso em algum momento publica, de vez em quando, um livro de caligrafia decorado, extremamente ornado e elegantemente guarnecido com muitas folhas em branco; a multidão assim olha para este fenômeno elegante com espanto e admiração e pensa que se demorou tanto para escrevê-lo e se há tão pouco na página, então deve ser algo extraordinário. Se, por outro lado, um autor pleno de ideias, que tem o pensar para além da ornamentação e do lucrar com a ilusão, extenuando-se com cada vez mais diligência, vê-se capaz de trabalhar com uma velocidade incomum, então a multidão com isso se acostuma e pensa: isto deve ser desleixado. Pois, é claro, a multidão não pode julgar se algo está bem feito ou não, ela fica apegada à - ilusão. Se um pastor, como por exemplo o tão dotado Capelão de Berlim recém-falecido, Theremim ${ }^{21}$, prega apenas a cada oitavo domingo, ou mesmo a cada décimo segundo, mas o faz na presença mais elevada da majestade e de toda a casa real: então isso imediatamente faz nascer uma ilusão com relação ao Pregador da Corte [Oberhofpradikant. Ele se torna - sim, em verdade ele naturalmente se torna aquilo que ele realmente é: um homem altamente dotado, mas aos olhos da multidão ele se torna, além de ser o Pregador da Corte, um Pregador da Cidade [Stadspradikant] ou um imponente [stadselig] Pregador da Corte, algo imponente, algo como a carruagem dourada do rei que se vê maravilhado algumas vezes por ano. A multidão ficará espantada: em sua sabedoria pensará assim: se alguém passa 3 meses sozinho para preparar uma pregação e para aprendê-la de cor, ele deve realmente ser alguém extraordinário. Veja, a aglomeração seria tão grande para com aqueles curiosos e tão esperados oitavos ou décimo segundos domingos que o Pregador da Corte dificilmente chegaria ao púlpito - se pregasse apenas uma vez por ano a aglomeração seria tão grande que ele não seria capaz de descer do púlpito, ou sacristãos armados e policiais seriam necessários para permitir a entrada e a saída do mais venerável Pregador da Corte. Tão grande seria a aglomeração, e se acontecesse de alguém perder a vida na aglomeração, então a aglomeração tornar-se-ia ainda maior na próxima vez, pois se aplica não apenas em relação à verdade, mas também em relação à curiosidade: "sanguis martyrum est semen ecclesiae" [o sangue dos mártires é a semente da igreja]22.

21 Ludwig Friedrich Franz Theremin (1780-1846) foi um sacerdote alemão que lecionou na Universidade de Berlim. Em seus últimos anos, Theremin, embora famoso por seus sermões e pregações, já não os fazia com muita frequência, de modo que o público recebia com entusiasmo os momentos em que se dispunha a pregar. Faleceu em 1846, pouco tempo antes de Kierkegaard iniciar a redação deste ensaio, de modo que a referência era conhecida por seus contemporâneos.

22 A máxima cristã é derivada de uma sentença escrita por Tertuliano em seu Apologeticus adversus gentes pro christianis, onde consta: "Plures efficimur, quotiens metimur a vobis: semen est sanguis Christianorum" [Tornamo-nos mais numerosos conforme somos ceifados por vós: a semente é o sangue dos cristãos]. Kierkegaard possuía em sua biblioteca uma edição das obras de Tertuliano em latim publicada em Leipzig. 
E agora uma atriz que tem sido constante objeto de admiração por 14 anos. Ela agora foi vista muitas vezes e as pessoas adormeceram nesta admiração; sabe-se, por certo, que ela permanece no país - pois se fosse uma dessas que viajam pela Europa, no entanto, poderia ainda ter sua esperança pela assistência da ilusão; sabe-se, por certo, que ela deve ficar na cidade, porque na Dinamarca há apenas uma cidade e um teatro; sabe-se, por certo, que ela deve atuar, pois está sob um contrato; muitas pessoas, apesar da admiração, talvez sejam rudes o suficiente para estarem cientes de que ela precisa atuar porque esse é o seu meio de vida; sabe-se, por certo, que é possível vê-la geralmente duas vezes por semana. Não é preciso dizer que continua a ser admirada; mas quantos contemporâneos são igualmente capazes de preservar a vigilância da interioridade e da apreciação de modo que, no $14^{\circ}$ ano de admiração, ainda possam vê-la com a mesma originalidade, com a mesma originalidade que ela preserva! Não, a humanidade se parece, nestes casos, com as crianças na feira da praça $a^{23}$ que, ao perceber que têm algo e que são autorizadas a mantê-lo, tornam-se ingratas e, se não exatamente ingratas, então ao menos indolentes no hábito da admiração. A ninguém, portanto, as pessoas são tão ingratas quanto a Deus, precisamente porque têm uma preguiçosa impressão de que é sempre possível tê-lo - ah, ele não pode, nem morrendo, fazê-los sentir o que perderam. Ah, admiração humana, quão completamente vaidosa você é, mesmo quando julga ser constante [at vare stadig]!

Não há nenhuma mudança, então, na expressão da admiração e do reconhecimento, apenas na entonação; o spiritus asper [espírito áspero] da primeira impressão abrandou-se no fraco aspirar de uma admiração relutante e perecível. As ações da atriz permanecem inalteradas na cotação de preços, mas não de maneira tão rígida; uma insidiosa, angustiante e fundamentalmente bem-intencionada, mas em sua curiosidade ainda traiçoeira reflexão começa a sussurrar que ela está envelhecendo. Ninguém vai admitir, mas é dito, e ainda assim ninguém vai admitir tê-lo dito. Precisamente porque sua existência tem sido uma questão nacional, a tensão do constrangimento é mais dolorosa. Deseja-se o bem para ela (não pretendemos nos deter sobre o papel que a inveja de indivíduos singulares pode ter na origem de tal opinião); as pessoas estão realmente zangadas com o tempo, que fará com que ela fique mais velha agora que todos já se acostumaram, graças ao hábito da admiração, a pensar que deveria sempre ter 18 anos de idade; e no entanto não conseguem acalmar-se em relação a esse pensamento de que ela envelhece. Ninguém pensa no grau da ingratidão com que tornam mais e mais difícil essa metamorfose, no grau da ingratidão com que a recompensam por transformar a memória em oposição no instante decisivo - e ninguém pensa na possibilidade de que todo esse galimatias ${ }^{24}$ esteja fora de lugar, ao menos esteticamente, já que precisamente com a metamorfose seu tempo verdadeiro [Tidsregning ret] propriamente começará.

23 Referência à passagem bíblica encontrada em Mateus 11:16-17.

24 Galimathias, no original; trata-se de um discurso enredado e confuso, cujo sentido não se pode captar. 


\section{IV}

\section{(Último Artigo)}

Então agora para a metamorfose. O que constituía essa atriz não era o que se chamaria de juventude feminina. Assim sendo, essa juventude é uma presa dos anos; por mais amoroso, por mais cuidadoso que o tempo seja ao levá-la embora, ainda assim leva embora tudo aquilo que é temporário. Mas nessa atriz havia um gênio essencial que estava relacionado a essa ideia: juventude feminina. Esta é uma ideia, e uma ideia é algo bem diferente da exterioridade [Phanomenale selv] de se ter 17 anos de idade, que é também o caso da menina mais sem-ideia [ideelose] que chega aos 17 anos de idade. Se essa relação de genialidade com a ideia não tivesse ocorrido, não se poderia falar em metamorfose; mas precisamente porque este é o caso, e a ideia é o que é, a metamorfose pode tornar-se uma raridade. Como a natureza, por sua previsão e por sua recordação retrospectiva, que os cientistas da natureza chamam de prometeico e epimeteico ${ }^{25}$, e que preserva a sua continuidade: assim também com relação ao espírito as coisas que devem servir para constituir a metamorfose devem estar presentes desde o início, embora não sejam decisivamente usadas ou não se manifestem decisivamente antes que algum tempo tenha passado - isto é precisamente a metamorfose.

Aquela que tem a juventude feminina apenas em uma compreensão simples não pode ter a metamorfose, porque a juventude feminina nessa compreensão não é intrinsecamente dialética, é apenas uma vida que, pela ocorrência da dialética, não pode ser dividida e isolada, mas simplesmente consumida. O tempo é a dialética que vem de fora e, portanto, consome rapidamente ou lentamente a juventude não-dialética. Mas onde há uma vida a mais, ali o tempo, tirando um pouco da simples juventude, torna a genialidade mais manifesta, e manifesta na relação puramente estética da idealidade com o ideal. Claro, ela não será jovem novamente no sentido ridículo que o assistente de açougueiro e o púbico falam sobre uma diabolicamente atrevida garota, mas apenas no sentido da idealidade ela será mais e mais jovem. Ela agora é apropriadamente o objeto para uma crítica essencial, agora que, pela segunda vez e em uma segunda potência, relaciona-se com a mesma ideia ou, dito de forma mais precisa, justamente porque é a segunda vez que ela se relaciona de forma puramente ideal com a ideia. O caso é bem simples; pode-se perguntar, então: que moldura

25 Kierkegaard faz um jogo com as duas características atribuídas à natureza e o nome dos dois titãs gregos. A característica de previsão, em dinamarquês fremsynethed, estaria relacionada com Prometeu,

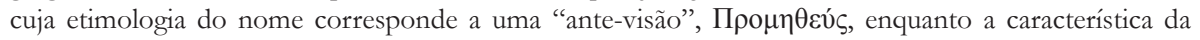
recordação retrospectiva, em dinamarquês erindrende tilbageseen, estaria relacionada com Epimeteu, cuja etimologia do nome corresponde a um “pós-ver”, ou pensar depois, 'E $\pi \mu \eta \theta \varepsilon u ́ c$. Kierkegaard retira essa imagem e comparação de cunho científico-natural do livro do médico alemão Carl Gustav Carus, Psyche. Zur Entwicklungsgeschichte der Seele [Psique. Para uma história do desenvolvimento da alma], o qual constava em sua biblioteca. 
corresponde essencialmente a um gênio cuja ideia é a juventude feminina? A maioria das pessoas, infelizmente, provavelmente responderia: é a juventude feminina ou ter 17 anos de idade. Mas esse é certamente um mal-entendido que conflita com a própria mentalidade da dialética [Dialektiskes egen Tankegang]. O puro ideal e o dialético são requeridos: que a moldura ou o lugar onde a ideia se encontra relacione-se com a ideia a uma certa distância da ideia. Em relação a todas as determinações da natureza, é verdade que a primeira vez é a mais elevada, é a culminação; no sentido da idealidade é verdade que a segunda vez é a mais elevada, pois o que é o ideal, senão precisamente isto: a segunda vez? A ideia de juventude como uma tarefa e o ser muito jovem certamente não correspondem corretamente um com o outro na compreensão da idealidade. Uma vez que os espectadores inestéticos são de opinião oposta, isto se dá porque são enganados por uma ilusão que confunde a alegria para com a juventude exterior da Srta. Fulana com a idealidade essencial da atriz. Vamos dar outro exemplo. Há um lirismo que deve ser chamado de lirismo da juventude; toda pessoa jovem erectionis ingenii [intelectualmente dotado] tem um pouco disso. Mas um jovem que tem a juventude qua juventude tem esse lirismo da juventude e tem também gênio, cuja ideia é o lirismo da juventude: agora perguntemos, quando ele realizará o seu melhor lirismo, com seus 20 anos? De maneira nenhuma. Seu melhor lirismo virá em uma idade um pouco mais avançada, quando o tempo tomar os felizes acidentes de sua juventude, já em relação de pura idealidade e, assim, em um sentido profundo, ao servir, ele se relaciona com a ideia. Aqueles que têm uma percepção apenas sobre a primeira felicidade juvenil carecem de formação estética e, portanto, não descobrem que essa felicidade é o acidente e o perecível, enquanto o gênio e a relação com a ideia são o eterno e o essencial.

A tarefa mais importante que é posta para uma atriz que se relaciona com a ideia de juventude feminina em sua potência mais rica é provavelmente a de Julieta em Romeu e Julieta. Será que realmente ocorreria a algum esteta que uma atriz de 17 anos pudesse interpretar Julieta? Fala-se, é verdade, tremendamente sobre todo esse jogo de forças, esta chama, este fogo e de muitas outras coisas semelhantes; mas fala-se propriamente disso em categorias de galeria [Galleri-Kategorier] ${ }^{26}$, e tais categorias não são suficientes para julgar uma concepção de Julieta. O que a galeria quer ver, é claro, não é uma performance ideal, uma representação da idealidade: a galeria quer ver a Srta. Julieta, uma diabolicamente linda e amaldiçoadamente atrevida garota de 18 anos que interpreta Julieta ou que se passa por Julieta, enquanto a galeria se entretém por pensar que é a Srta. Fulana. Portanto, a galeria naturalmente nunca consegue ter em mente que uma atriz, para representar Julieta, deve essencialmente ter uma distância de idade de Julieta. E no entanto é assim, e aquela

26 Em dinamarquês a expressão "spil for galleriet", que poderia ser traduzido literalmente por "atuar para a galeria", tem a conotação de uma apresentação ou uma performance hipócrita ou forçada que serve apenas para agradar às pessoas que se encontram nas galerias, ou seja, aqueles lugares que eram considerados menos prestigiados porque eram comumente ocupados por pessoas com menor capacidade aquisitiva, dado o menor valor dos ingressos. Em suma, trata-se de uma expressão no sentido de agradar ao público geral ou a massa. Categorias de galeria são, portanto, baseadas sob esta conotação específica. 
admirada abundância de forças no $18^{\circ}$ ano é realmente, esteticamente, um mal-entendido, pois no ideal a melhor força é a consciência e a transparência que sabe como dispor das forças essenciais - mas, note-se bem, a serviço de uma ideia. Certamente há tarefas dadas a uma atriz em relação às quais os 18 anos são quod desideratur [o que é desejado]: mas essas tarefas não são exatamente as tarefas eminentes. Há tarefas em que essa força esmagadora da primeira juventude deve ser usada como um adorável jogo. Estas tarefas podem ser assumidas por tal atriz, e estas então podem ser consideradas como um belo e também significativo passatempo até que ela se torne mais velha e, com as forças essenciais, possa realizar as tarefas eminentes. Representar uma pequena senhorita de 16 anos em um drama francês, essa será a tarefa apropriada ${ }^{27}$. Mas suportar essa fragilidade volátil e enganosa é também nada em comparação com suportar o peso da intensa profundidade de Julieta. É evidente que seria um mal-entendido pensar que qualquer pessoa capaz de representar uma figura quase que esboçada apenas com o passar do tempo seria capaz de assumir as tarefas eminentes. Não, longe disso. Mas é precisamente por isso raro quando aquela que, absolutamente feliz, continuamente revigorada e rejuvenescida, formada nas leves figuras das ninfas flutuantes ${ }^{28}$, quando na plenitude do tempo transforma-se na hipóstase eminente.

A metamorfose tornar-se-á, então, em um sentido eminente, no retorno ao seu primeiro estado. Isso será agora mais bem elucidado ao se indicarem as determinações dialéticas na metamorfose. O tempo é, como se diz, a dialética que vem de fora, mas ela era originalmente dialética em si mesma, precisamente por isso ela pode resistir ao tempo, por isso a dialética do tempo só torna evidente a dialética que há nela - na metamorfose.

O tempo tornou seu direito aplicável; ele mitigou algo do imediato, do primeiro, do simplório, da juventude acidental. Mas a essa altura o tempo por sua vez tornará sua genialidade mais essencialmente manifesta. Ela perdeu-se para os olhos da galeria, mas

27 Kierkegaard faz referência às apresentações que fez Johanne Luise Heiberg da peça Les Premières Amours, ou Les Souvenirs d'enfance, de Eugène Scribe, em 1831, na qual interpretava a personagem Emmeline. Quando estreou neste papel, em 10 de junho de 1831, a atriz tinha então 18 anos, tendo atuado na peça dezenas de vezes, sendo sua última apresentação em 1837. Kierkegaard já havia tecido comentários sobre essa apresentação no trecho de O Primeiro Amor, presente na primeira parte de Enten-Eller [Ou isso... ou aquilo...]. O elogio, anteriormente, se devia à capacidade de encanto e sedução daquela jovem atriz, tom que se adaptava ao âmbito puramente estético daqueles textos. Ao fazer referência ao seu próprio comentário anterior, Kierkegaard está demarcando a diferença essencial no tratamento dado à análise da "tarefa da atriz", como ele mesmo indica.

28 No original em dinamarquês: "de flygtige Bolgepigers lette Skikkeelser". Faz-se uma referência às figuras mitológicas conhecidas como as nove filhas do deus do mar, Æger (também conhecido como Gymir), e sua esposa Ran. Segundo o mito, as jovens nadam no oceano ao redor de sua mãe e emergem das ondas adornadas em um véu branco. Estão presentes tanto na Edda Poética quanto na Edda em Prosa, sendo que nesta última aparecem como uma forma de referir-se ao mar na seção Skáldskaparmál. Não é raro que Kierkegaard faça uso dessas figuras poéticas, tanto da mitologia nórdica quanto da mitologia greco-romana e daquela própria do cristianismo para explicitar um ponto que, dito de outra maneira, perderia tanto a potência expressiva quanto a plenitude do sentido. 
ganhou no sentido da idealidade. O tempo das confusões da galeria acabou; se ela interpretar Julieta, não se pode mais falar em criar um furore como Srta. Julieta; se ela vai interpretá-la, deve ser uma performance eminente, ou, ainda mais corretamente, uma performance no sentido eminente. E isto é precisamente a metamorfose. Dureza contra dureza, como dizem, e também aqui: dialética contra dialética, então o tempo não tem o poder para realmente mitigar, ele é apenas um servo do poder que serve para tornar manifesto.

O tempo tornou seu direito aplicável; ele levou algo daqueles primeiros acidentes felizes ou daquela felicidade acidental da juventude, mas também, formando e refinando, desenvolveu-a, assim que ela agora, plena e conscientemente, na capacidade adquirida e alcançada sobre sua força essencial, pode ser verdadeiramente a serva de sua própria verdade, que é a relação essencialmente estética e essencialmente diferente da relação imediata que aquela de 17 anos tinha com sua própria juventude. Esta é relação de servidão com a ideia, que é propriamente a culminação, esta consciente autossubmissão à ideia é precisamente a expressão da eminente elevação da performance. A juventude dos 17 anos é demasiado recatada, demasiado autoconfiante, demasiado feliz para servir no mais profundo ou, o que dá no mesmo, no mais elevado sentido. Mas isto, de servir totalmente, é o arrebatamento; o arrebatamento de alguém com 17 anos é essencialmente um ansiar para fora, que em toda a sua felicidade nunca pode estar seguro diante de um ou outro acidental; ou, se for evitado que o acidental apareça, é preciso dizer sempre: isto foi uma felicidade, porque isto é sempre possível. Somente na relação absoluta com a ideia é que o acidental é tornado absolutamente impossível.

O tempo tornou seu direito aplicável; há algo que se acabou; mas então uma idealidade de lembrança lançará uma luz mais elevada sobre toda a performance, uma encarnação que não estava presente mesmo nos dias da primeira juventude. Apenas na lembrança há absoluta calma e, portanto, apenas o fogo silencioso do eterno é o seu brilho inquebrantável. E ela tranquilizou-se na eternidade de sua genialidade essencial; não quer, infantilmente ou lamentavelmente, ansiar pelo incandescer daquilo que se esvai, porque na metamorfose tornou-se demasiado quente e demasiado rica para tanto. Essa lembrança pura, reconfortante e rejuvenescedora passará, como uma luz idealizadora, por toda a performance, que nesta iluminação será completamente transparente.

Esses são os momentos da metamorfose. Agora, mais uma vez, para iluminar sua peculiaridade por outro lado, vamos concluir, comparativamente, justapondo outra metamorfose. Nós escolhemos uma que é qualitativamente diferente; isso dará à comparação um interesse real, enquanto evitará que todos os curiosos fiquem quantificando qual é a mais rara, etc. Esta segunda metamorfose é aquela da continuidade, a qual, por sua vez, mais precisamente determinada, é um processo, uma sucessão, uma transformação constante ao longo dos anos, para que a atriz, à medida que envelhece, mude de tema, assuma papéis mais velhos novamente com a mesma perfeição que em uma idade mais jovem preencheu papéis mais jovens. Esta metamorfose poderia ser chamada simplesmente de perfectibilidade. É de particular interesse ético e será em grande medida agradável e 
convincente para um ético que na batalha por sua visão de vida orgulhosamente aponta para tal fenômeno como se fosse sua vitória, em silenciosa e interna gratidão, e chama a esta atriz de sua onipotente aliada, porque ela, melhor que ele, e precisamente em um dos pontos mais perigosos, prova a sua teoria. A metamorfose sobre a qual falamos, no entanto, é a da potenciação, ou a de um retorno mais e mais intenso para o início. Esta metamorfose ocupará absolutamente um esteta, pois a dialética da potenciação é a dialética estético-metafísica. Mais feliz que Arquimedes, ele ditirambicamente bradará "Eureca", apontando para o fenômeno; ébrio de admiração e ainda sóbrio na temperança dialética, só terá olhos para este e o entenderá como o seu chamado para criar as condições para que o maravilhoso possa ser visto e admirado enquanto tal. A metamorfose da continuidade irá, através dos anos, se espalhar igualmente sobre a extensão essencial de tarefas dentro da ideia de feminilidade; a metamorfose da potenciação irá, ao longo dos anos, relacionar-se de maneira mais e mais intensiva para com a mesma ideia, que, note-se bem, esteticamente entendida, é sensu eminentissimo [no sentido mais eminente] a ideia do feminino. Diz-se da atriz que corresponde à metamorfose da continuidade que se torna mais velha no sentido ideal, mas não mais velha no sentido da temporalidade; então no que diz respeito à outra metamorfose deve-se dizer que está ficando mais jovem. Mas deve-se dizer sobre ambas que o tempo não tem poder sobre elas. Há uma resistência ao poder dos anos, isto é, a perfectibilidade, e é precisamente ao longo dos anos que ela se desdobra; e há outra resistência ao poder dos anos, que é a potenciação, e é precisamente ao longo dos anos que ela se torna manifesta. Ambos os fenômenos são raridades essenciais, e ambos têm em comum o fato de que se tornam mais raros a cada ano. Precisamente porque são dialeticamente compostos, sua existência ano após ano tornar-se-á dialética; todos os anos tentará provar sua tese sobre o poder dos anos, mas a perfectibilidade e a potenciação refutarão vitoriosamente a tese dos anos. Isto novamente dá uma calma absoluta ao espectador, pois a juventude dos 17 anos é frágil, mas a perfectibilidade e a potenciação são a confiabilidade absoluta.

Se com este pequeno artigo consegui contribuir com algo para deixar claro o quão afortunado, apesar dos anos, o futuro da atriz essencial é, isto seria para mim uma amável satisfação, ainda mais porque tenho certeza de que, de muitas maneiras, há suficientes mal-entendidos em relação à percepção correta do futuro da atriz, na medida em que o mesmo mal-entendido, que errônea e inesteticamente superestimou o começo, errônea e inesteticamente incorre em falhas quanto ao que vem depois ou, mais corretamente, com o que há de mais elevado.

Verão de 1847. 